\title{
Mouse models of the fragile $X$ premutation and fragile X-associated tremor/ataxia syndrome
}

\author{
Robert F Berman ${ }^{1 *}$, Ronald AM Buijsen ${ }^{2}$, Karen Usdin ${ }^{3}$, Elizabeth Pintado ${ }^{4}$, Frank Kooy ${ }^{5}$, Dalyir Pretto ${ }^{6}$ \\ Isaac N Pessah, David L Nelson ${ }^{8}$, Zachary Zalewski ${ }^{8}$, Nicholas Charlet-Bergeurand ${ }^{9}$, Rob Willemsen ${ }^{2}$ \\ and Renate K Hukema ${ }^{2}$
}

\begin{abstract}
Carriers of the fragile X premutation (FPM) have CGG trinucleotide repeat expansions of between 55 and 200 in the 5'-UTR of FMR1, compared to a CGG repeat length of between 5 and 54 for the general population. Carriers were once thought to be without symptoms, but it is now recognized that they can develop a variety of early neurological symptoms as well as being at risk for developing the late onset neurodegenerative disorder fragile $X$-associated tremor/ataxia syndrome (FXTAS). Several mouse models have contributed to our understanding of FPM and FXTAS, and findings from studies using these models are summarized here. This review also discusses how this information is improving our understanding of the molecular and cellular abnormalities that contribute to neurobehavioral features seen in some FPM carriers and in patients with FXTAS. Mouse models show much of the pathology seen in FPM carriers and in individuals with FXTAS, including the presence of elevated levels of Fmr 1 mRNA, decreased levels of fragile $X$ mental retardation protein, and ubiquitin-positive intranuclear inclusions. Abnormalities in dendritic spine morphology in several brain regions are associated with neurocognitive deficits in spatial and temporal memory processes, impaired motor performance, and altered anxiety. In vitro studies have identified altered dendritic and synaptic architecture associated with abnormal $\mathrm{Ca}^{2+}$ dynamics and electrical network activity. FPM mice have been particularly useful in understanding the roles of Fmr1 mRNA, fragile X mental retardation protein, and translation of a potentially toxic polyglycine peptide in pathology. Finally, the potential for using these and emerging mouse models for preclinical development of therapies to improve neurological function in FXTAS is considered.
\end{abstract}

Keywords: CGG trinucleotide repeat, FMR1, FMRP, Fragile X premutation, FXTAS, Intranuclear inclusions, Mouse models, RNA toxicity

\section{Introduction}

The Fragile $\mathrm{X}$ mental retardation 1 gene (FMR1) is located on the long arm of the X-chromosome at Xq27.3 and codes for the fragile $\mathrm{X}$ mental retardation protein (FMRP), which is necessary for normal brain development and synaptic plasticity [1-5]. The fragile $\mathrm{X}$ gene carries a variable number of CGG repeats in the $5^{\prime}$-UTR of between 5 and 55 in most individuals (modal value 32 to 33; Figure 1). However, due to instability of the repeat across generations, there are large numbers of individuals who carry an expanded CGG repeat of between 55 and 200. These

\footnotetext{
* Correspondence: rfberman@ucdavis.edu

'Department of Neurological Surgery, Room 502C, UC Davis, 1515 Newton Court, Davis, CA 95618, USA

Full list of author information is available at the end of the article
}

individuals are referred to as fragile $\mathrm{X}$ premutation (FPM) carriers, and occur in the general population with an estimated frequency of 1 in 209 females and 1 in 430 males $[6,7]$. Further expansion of the CGG repeat to greater than 200 in the offspring of FPM carriers leads to the full mutation, silencing of FMR1 expression and fragile $\mathrm{X}$ syndrome (FXS), the major known inherited cause of intellectual disability $[4,8]$.

Carriers with 55 to 200 CGG repeats were originally thought to be clinically unaffected. However, it is now known that they can develop a variety of neurological symptoms, including memory problems, deficits in executive function, depression, anxiety, and problems with numerical processing and magnitude estimates $[3,10,11]$. They are also at risk for developing the late
C Biomed Central 


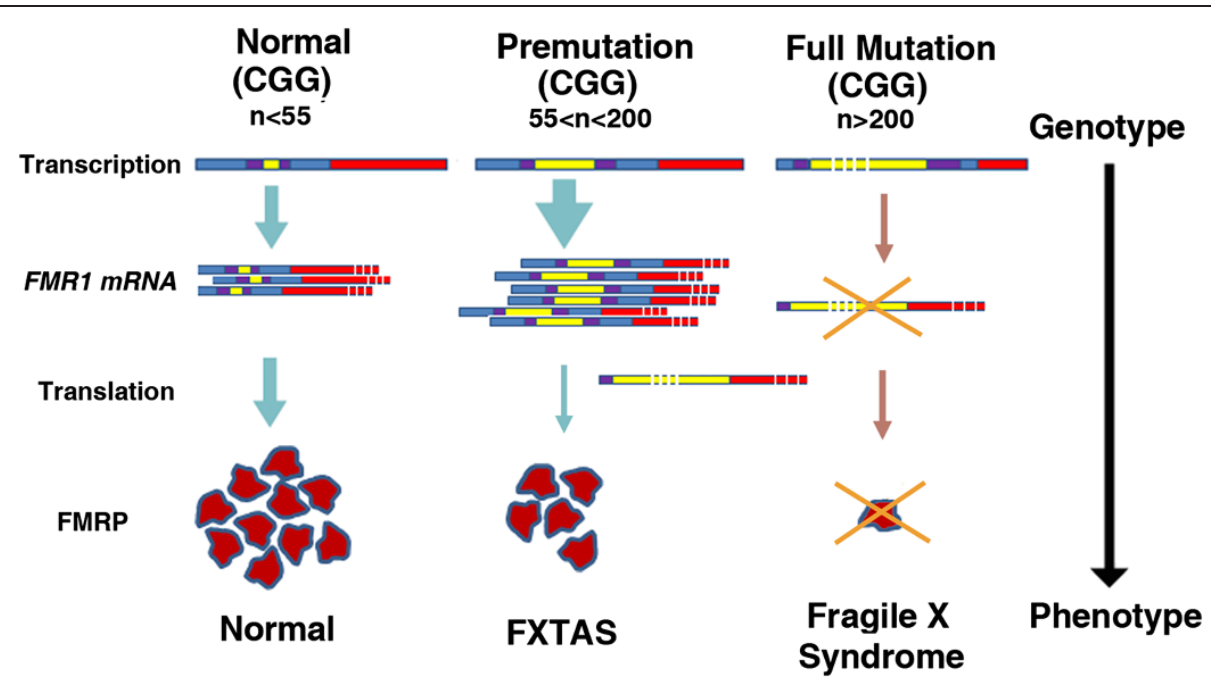

Figure 1 Most individuals in the general population have between 5 and 54 CGG trinucleotide repeats in the $5^{\prime}$-UTR of FMR1. Repeat length in the fragile X premutation range is 55 to 200, resulting in an elevation in FMR1 mRNA levels, a moderate decrease in FMRP and an increased risk of developing FXTAS. Repeat size in the full mutation is $>200$; FMR1 transcription is silenced due to DNA hypermethylation, and the absence of FMRP results in fragile $X$ syndrome. (Adapted from [9].) FMRP, fragile X mental retardation protein; FXTAS, fragile X-associated tremor/ataxia syndrome.

onset neurodegenerative disorder fragile X-associated tremor/ataxia syndrome (FXTAS). Major symptoms of FXTAS include tremor, ataxia, impairments in executive function and memory, and cognitive decline and dementia in some patients [12,13]. Neuropathology includes brain atrophy, ventricular enlargement, loss of Purkinje neurons, white matter disease, disruption of nuclear lamin $\mathrm{A} / \mathrm{C}$ architecture and accumulation of intranuclear protein inclusions $[5,14]$.

The chances of developing FXTAS increase dramatically with age, with approximately $45.5 \%$ of male and $16.5 \%$ of female FPM carriers over the age of 50 developing FXTAS [15]. Indeed, FXTAS may be one of the more common causes of tremor and ataxia in older adults [16]. Besides age, the risk factors that lead to the development of FXTAS in some, but not all, FPM carriers are unknown, but are likely to include CGG repeat length, additional genetic mechanisms and environmental factors (for example, environmental toxins, other illnesses [3]). Identifying the risk factors for FXTAS is particularly important and animal models will undoubtedly play a major role in this area of research.

Because of the increase in the number of people reaching the age of 65 , it is likely that the number of cases of FXTAS will increase accordingly, further highlighting the importance of research on FXTAS [16]. Therefore, it is important to understand the underlying pathology in FXTAS, to establish its developmental time course, and to develop rational treatments to delay or halt progression of disease and improve neurological function.

\section{Review}

Pathogenesis in affected FPM carriers and in FXTAS

Pathology in affected FPM carriers and in individuals with FXTAS is thought to be the result of RNA toxicity caused by 2 - to 8 -fold elevated levels of CGG-repeatbearing FMR1 mRNA. As depicted in Figure 2A, elevated Fmrl mRNA with a CGG repeat expansion is thought to sequester proteins critical for normal cell function, resulting in pathology. This hypothesis is supported by the finding that inclusions isolated from postmortem brain tissue from patients with FXTAS contain FMR1 mRNA and over 30 proteins, many critical for normal cell function, such as lamin A/C, $\gamma \mathrm{H} 2 \mathrm{AX}$, Sam 68, drosha, Ku86 and hnRNPA2 [17-19]. However, recent findings have suggested an additional model for toxicity, as depicted in Figure 2B, in which a potentially toxic polyglycine-containing peptide is produced as the result of a CGG repeat-mediated nonATG translation (RAN) mechanism [20]. Research using animal models has provided much of the evidence supporting these theories as presented in this review.

\section{Development of mouse models}

Several mouse models have been developed to study the FPM and FXTAS. These models show much of the pathology associated with CGG repeat expansions on FMR1. Table 1 compares pathology seen in FXTAS with that reported in CGG knock-in (KI) mouse models, including molecular, histological and some behavioral deficits. However, no models have been completely successful in 


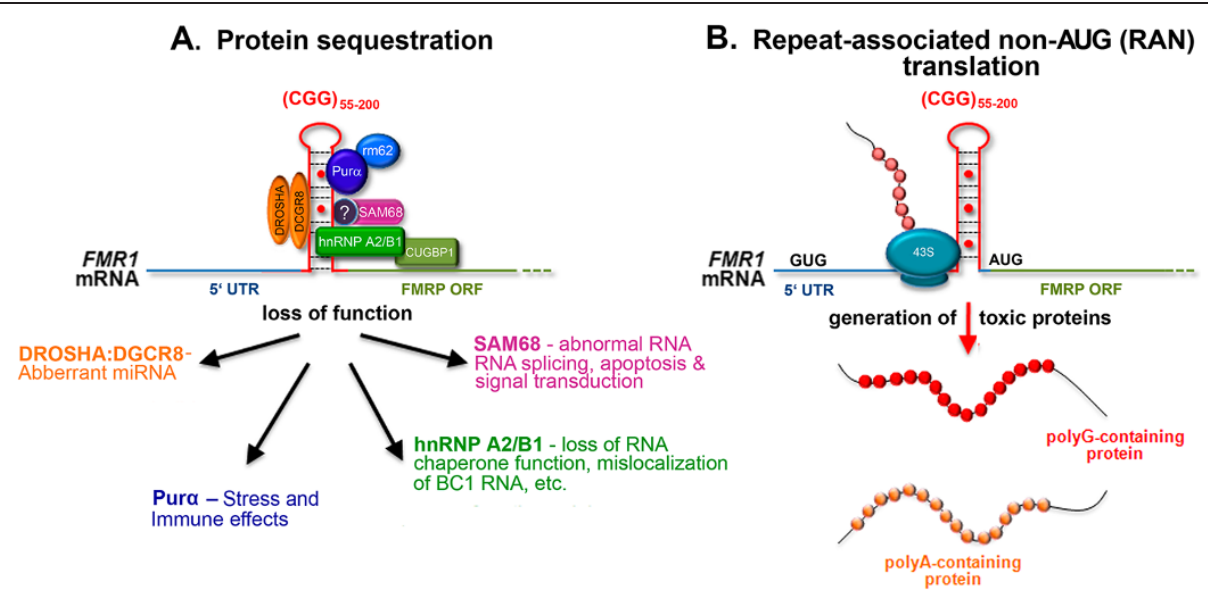

Figure 2 Potential mechanisms of CGG-repeat RNA toxicity in FMP carriers. (A) Protein sequestration model: RNA binding proteins are sequestered through their interactions with the expanded CGG-repeat RNA. These proteins can in turn recruit other proteins. The net result of sequestration of these proteins is that they are unavailable to carry out their normal functions and critical cellular processes are thereby altered or blocked. (? -Sequestration of SAM68 by CGG expanded repeats is indirect, presumably through protein-protein interactions). (B) Toxic polypeptide model: The 43S translation initiation complex stalls near the CGG repeat hairpin formed on the FMR1 RNA. This promotes the repeat-associated non-AUG translation of FMR1 mRNA using a near-AUG start site. This results in a frame shift and the production of polyglycine- and/or polyalanine-containing polypeptides that somehow interfere with normal cell function or may be directly toxic. FMRP, FMRP, fragile X mental retardation protein; ORF, open reading frame; polyA, polyalanine; polyG, polyglycine.

reproducing all of the features reported in affected FPM or individuals with FXTAS. An important example is the absence of any reports of obvious tremor in current mouse models, a defining neurological feature of FXTAS. Therefore, it is acknowledged at the outset that current mouse models only partially recapitulate features of the FPM and FXTAS. The mouse models described below have been developed to study specific aspects of disease associated with CGG repeat expansions; each offers advantages and limitations, and each has already provided important insights into disease mechanisms.

\section{The Dutch mouse}

The study of FXS and FXTAS has been greatly facilitated by the development of animal models that mimic much of the pathology associated with these disorders. The first mouse model of FXTAS and the FPM was a CGG KI mouse model from the Willemsen laboratory in the Netherlands, the so-called Dutchmouse $\left(\mathrm{CGG}_{\mathrm{dut}} \mathrm{KI}\right)$. This mouse model was generated by replacing the native murine CGG repeat eight trinucleotides in length (CGG8) within the endogenous $F m r 1$ gene with a human CGG98 repeat by homologous recombination in embryonic stem cells [22]. Importantly, while minimal changes to the murine Fmr1 promoter were made when the targeting construct containing the human $(\mathrm{CGG})_{98}$ repeat was generated, the region flanking the repeat in the human FMR1 was included. These CGG KI mice show moderate instability of repeat length upon paternal and maternal transmission, with both small expansions and contractions (that is, typically fewer than 10 repeats) [22-24]. These CGG $_{\text {dut }}$ KI mice have been bred onto a C57BL/6 J background over

Table 1 FXTAS compared to the CGG knock-in mouse model

\begin{tabular}{lll}
\hline Pathology & Human FXTAS & CGG knock-in mouse \\
\hline $\begin{array}{l}\text { CGG trinucleotide repeat } \\
\text { length }\end{array}$ & 55 to 199 CGG repeat length, repeat instability & 70 to 300 CGG repeats, modest repeat instability \\
$\begin{array}{l}\text { Elevated FMR1 mRNA } \\
\text { expression }\end{array}$ & Increased 2- to 8-fold & Increased 1.5- to 3-fold \\
$\begin{array}{l}\text { Fragile X mental } \\
\text { retardation protein levels }\end{array}$ & Reduced in several brain regions & Reduced in several brain regions \\
$\begin{array}{l}\text { Motor impairments } \\
\text { Cognitive Impairments }\end{array}$ & Tremor/ataxia, postural sway, parkinsonism & Impaired on rotarod and ladder rung task \\
Intranuclear inclusions & $\begin{array}{l}\text { Neurons and astrocytes, highly correlated with CGG repeat } \\
\text { length, frequency increases with age }\end{array}$ & Spatial memory deficits, altered anxiety-like behaviors \\
& repeat, frequency increases with age &
\end{tabular}


several generations to establish lines with expanded alleles ranging from 70 to greater than 300 CGG repeats [21,22]. Although expected, based on silencing of FMR1 expression in FXS, no increased methylation of the Fmr1 gene has been found even with longer CGG repeat expansions (for example, >300). As described below, these mice models exhibit much of the pathology seen in affected FPM carriers and in FXTAS, including increased expression of Fmr1 mRNA, decreased FMRP, ubiquitin-positive intranuclear inclusions (Figure 3) and evidence for motor and spatial processing deficits [21].

\section{The National Institutes of Health mouse}

A second KI mouse was developed at the National Institutes of Health with an initial CGG118 tract [26,27]. The $\mathrm{CGG}_{\text {nih }} \mathrm{KI}$ mice were generated using a different strategy from the $\mathrm{CGG}_{\text {dut }}$ mice. They were developed using a targeting construct in which exon 1 of the mouse gene was retrofitted with two adjacent but incompatible Sfi I sites. The repeats were generated in vitro in such a way that they were flanked by the appropriate $S f i$ I sites. This allowed the CGG repeats to be inserted into the mouse locus in the correct orientation and in such a way as to make minimal changes to the mouse flanking sequence. As a result of this strategy, the $C_{G G} G_{\text {nih }}$ mouse retains the translational TAA stop codon just upstream of the CGG118 repeat that is present in the endogenous murine gene but not the human gene. As with the $\mathrm{CGG}_{\text {dut }}$ mice, the $\mathrm{CGG}_{\text {nih }}$ mice show elevated Fmr1 mRNA levels, decreased FMRP levels, moderate intergenerational expansions, no methylation (even when repeat numbers were >300) and ubiquitin-positive intranuclear inclusions [26].

\section{Similarities and differences between $\mathrm{CGG}_{\text {dut }}$ and $\mathrm{CGG}_{\text {nih }}$ knock-in models}

The two CGG KI mouse models show similarities as well as some differences [26,28]. Both models show severalfold increases in levels of Fmr1 mRNA and a reduction in brain levels of FMRP that is inversely related to CGG repeat length. However, they differ in that the reduction in FMRP in the CGG $_{\text {dut }}$ KI mouse (20\% to $30 \%$ ) is typically much less than that reported in the $\mathrm{CGG}_{\text {nih }} \mathrm{KI}$ $(>50 \%)$. Ubiquitin-positive intranuclear inclusions are found in both models, but are more common in neurons and astrocytes in the $\mathrm{CGG}_{\text {dut }} \mathrm{KI}$ model [20]. Inclusions in $\mathrm{CGG}_{\text {dut }}$ KI mice are widespread in the brain, including the hippocampus, cortex, cerebellum, olfactory bulb, superior and inferior colliculi, and hypothalamus [24]. Purkinje cell loss is seen in postmortem tissue from FXTAS brains, as well as in the $\mathrm{CGG}_{\text {nih }}$ KI mouse, but has not been reported in the $\mathrm{CGG}_{\text {dut }} \mathrm{KI}$ mouse [26]. Behaviorally, there is evidence for memory impairment in both models [29,30], but the $\mathrm{CGG}_{\text {dut }}$ KI mouse shows increased anxiety [31] whereas the $\mathrm{CGG}_{\text {nih }} \mathrm{KI}$ mouse shows decreased anxiety [30]. Both models show modest intergenerational repeat instability. Neither model, however, reliably shows large expansions in the length of the CGG repeat tract seen with maternal transmission in FXS, and no methylation or silencing of Fmr1 expression has been reported in either model. This difference between humans and mice in the frequency of large germline expansions may be due to differences in the length of the perigametic interval in males of both
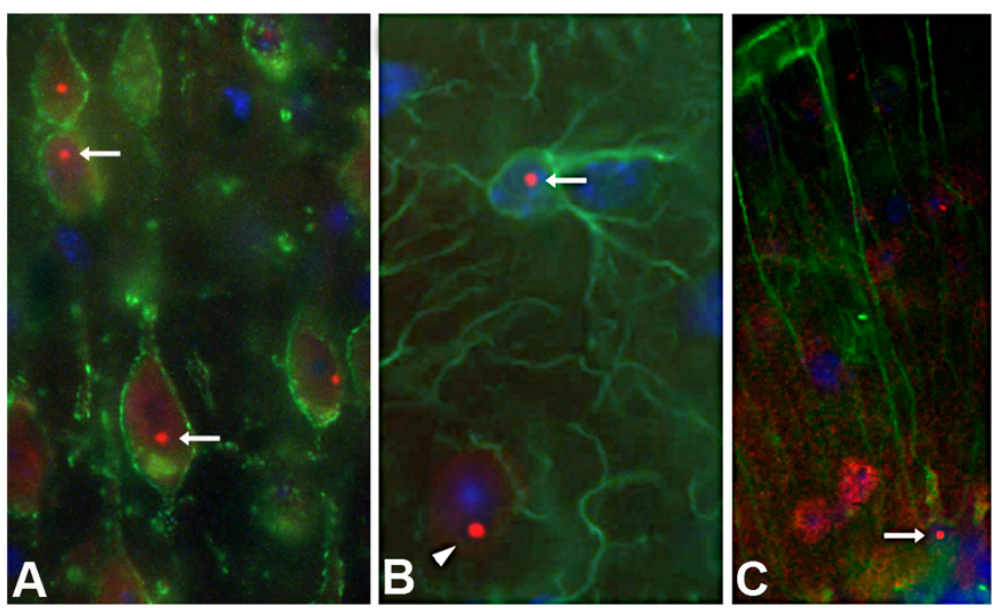

Figure 3 Ubiquitin-positive intranuclear inclusions in neurons and astrocytes of CGG $_{\text {dut }}$ knock-in mice. White arrows point to red punctate intranuclear inclusions in pyramidal neurons in motor cortex (A), cortical astrocytes (B) and Bergmann glia in cerebellum (C). Intranuclear inclusions (red) were labeled by immunofluorescence for ubiquitin, neurons (green) for Kv2.1 potassium channels, and astrocytes and Bergmann glia (green) for GFAP. In (B), note an intranuclear inclusion in an adjacent neuron (arrowhead). Nuclei were stained with DAPI. (Adapted from [25]). 
species (that is, weeks), female mice (months) and human females (decades) [32]. The levels of the proteins involved in generating or preventing expansions during the perigametic interval could also contribute to these differences [33].

The reasons for differences between the two models in FMRP reduction, Purkinje cell loss and the frequency of intranuclear inclusions are unclear given that both were generated with CGG repeat sequences that differed only by approximately 20 repeats. However, the cloning strategy used to make these mouse lines differed in that the $\mathrm{CGG}_{\text {nih }} \mathrm{KI}$ mouse retains a greater region of the mouse 5'UTR flanking the CGG repeat, including a TAA stop codon that is not present in the $\mathrm{CGG}_{\text {dut }} \mathrm{KI}$ mouse. The absence of this stop codon in the $\mathrm{CGG}_{\text {dut }}$ KI may allow RAN translation of a novel polyglycine protein that appears to contribute to CGG repeat toxicity in human cell lines and in a Drosophila model [20]; conversely, its presence in the $\mathrm{CGG}_{\text {nih }} \mathrm{KI}$ may block this CCG RAN translation. The ability to compare the pathology between the two mouse models represents an important and powerful tool for understanding the mechanisms of disease in the FPM and in FXTAS.

Ectopic expression of an expanded CGG90 in transgenic mice In order to determine whether ectopic expression of an expanded CGG90 repeat causes neurodegeneration in the cerebellum, transgenic mice (L7-CGG90-Fmr1) were developed in which expression was spatially restricted to cerebellar Purkinje neurons using the L7 promoter [34]. In these mice, the CGG90 repeat was upstream of either Fmr1 or enhanced green fluorescent protein (EGFP) cDNA (L7-CGG90-Fmr1, L7-EGG90-EGFP), with control mice expressing Fmr1 or EGFP but without a CGG90 repeat expansion (L7-Fmr1, L7-EGFP). Significant Purkinje cell loss was observed in 32-week-old L7-CGG90-Fmr1 and L7-CGG90-EGFP mice compared to wild-type (WT) littermates or L7-Fmr1/L7-EGFP mice (Figure 4). Ubiquitinpositive intranuclear inclusions were found in Purkinje neurons of both the L7-CGG90-Fmr1 and L7-CGG90EGFP lines, but were not found in either WT littermates or the L7-Fmr1 or L7-EGFP control lines. Lack of inclusions in control mice, in addition to their presence in the L7-CGG90-EGFP line, demonstrates an essential role for the CGG repeat expansion in inclusion formation, and that expressed CGG repeat containing RNA is sufficient to induce inclusions. These Purkinje neurons stained positive for the $20 \mathrm{~S}$ core complex of the proteasome, Hsp40, and $\operatorname{Rad} 23 \mathrm{~B}$. Interestingly, staining was negative for Pur $\alpha$, hnRNPA2/B1, Tau and $\alpha$-synuclein - all proteins that have been reported in human intranuclear inclusions in human FXTAS [18]. Motor performance on the rotarod was also impaired in mice expressing the CGG90 repeat compared
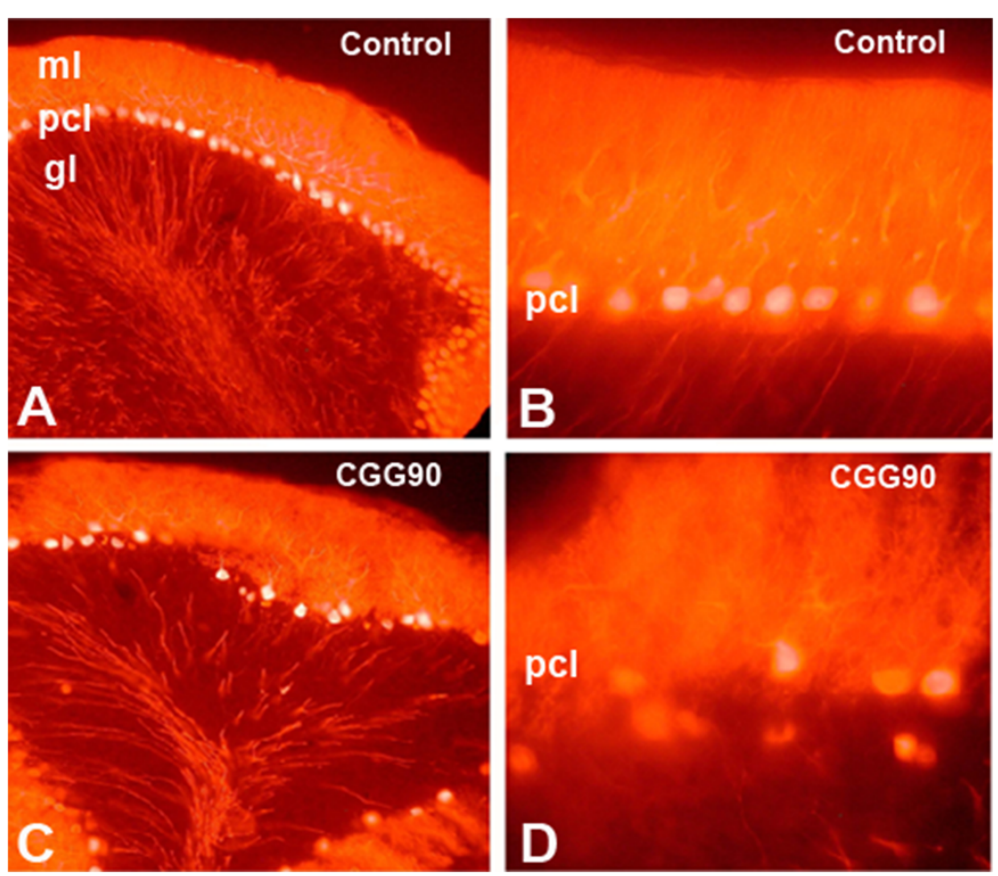

Figure 4 Ectopic expression of a CGG90 repeat results in Purkinje cell loss. (A) Cerebellum of control mouse without a CGG90 repeat (that is, L7Fmr1) showing normal distribution of Purkinje cells in the Purkinje cell layer. (B) Higher magnification of the Purkinje cell layer in control mouse. (C) Selective Purkinje cell loss in 32-week-old mouse expressing a CGG90 repeat under the L7 Purkinje cell-specific promoter (that is, L7CGG90Fmr1). (D) Purkinje cell loss in shown at higher magnification in L7CGG90Fmr1 mouse. gl, granule cell layer; ml, molecular layer; pcl, Purkinje cell layer. (Adapted from [34]). 
to controls, and this impairment was not age-related, as similar impairment was seen in 20- and 40-week-old mice. These results provide evidence that CGG repeat mRNA expression is sufficient to cause Purkinje neuron dysfunction and loss similar to that reported in FXTAS [35].

Neuropathological observations to date demonstrate a connection between formation of intranuclear inclusions and cell death. While it is tempting to speculate that the formation of inclusions is the cause of cell loss, such a conclusion is contingent upon understanding what the functional ramifications are when proteins and their interacting partners are sequestered within an inclusion body. A Drosophila model ectopically expressing premutationlength CGG repeats showed a neurodegenerative eye phenotype and Hsp70/ubiquitin-positive inclusions [36]. A subsequent genetic screen showed that CELF1 (CUGBP1), when ectopically expressed, was able to suppress the neurodegenerative eye phenotype [37]. CELF1 was also shown to directly interact with hnRNPA2/B1, known to be present in inclusions of patients with FXTAS [18]. CELF1 is up-regulated overall in the presence of CUG repeats $>50$, contributing to the mis-regulation of mRNA splicing and translation and the muscle atrophy and weakness observed in muscular dystrophy type 1 , the disease for which its involvement is best known [38-40]. CELF1 is therefore predicted to be one potential modifier of CGG repeat-mediated neurodegeneration. Preliminary findings in mice show modulation of neuropathological phenotypes previously reported in the L7CGG90 transgenic mice when the expression of CELF1 is altered (Zalewski et al. Abstracts of the 1st Premutation Meeting, Perugia, Italy, 2013). Such findings support an RNA toxicity mechanism (see Evidence for current disease models section), specifically that the sequestration of such proteins within an inclusion inhibits their normal function, leading to dysregulation (at least at the level of RNA processing) in the cell and, over time, cell death.

\section{Fmr1 overexpressing mice}

Levels of FMR1 mRNA bearing an expanded CGG are elevated several fold in premutation carriers and in patients with FXTAS, supporting the hypothesis that pathology is the result of FMR1 mRNA toxicity. However, the possibility exists that toxicity could be due to either the CGG repeat itself, elevated FMR1 mRNA independent of the repeat expansion, or both. In a Drosophila model of FXTAS, high expression levels of a CGG60 repeat causes formation of ubiquitin-positive inclusions and neurodegeneration in the retina in a dosage- and repeat length-dependent manner, whereas moderate expression of the repeat allele results in little pathology. These findings support the notion that overall abundance of a CGG repeat molecule may be important for generating a pathological phenotype [36]. To investigate the potential deleterious effects produced by overexpression of FMR1 mRNA with a normal CGG repeat length, transgenic mice that overexpress FMR1 mRNA bearing a normal length CGG29 repeat have been generated [41]. The CGG29 transgenic mouse was obtained by pronuclear injection of a construct containing the human FMR1 cDNA with 29 CGG repeats under control of a SV40/T7 promoter. This model results in a 20 - to 100 -fold increase in FMR1 mRNA in all tissues studied (for example, liver, cerebral cortex and cerebellum). However, these animals did not show significant differences from WT mice in general activity or anxiety-related behaviors in open-field tests. These results suggest it is expression of the expanded CGG repeat that is primarily responsible for pathology, and not overexpression of Fmr1 mRNA per se. Other transgenic mice overexpressing FMR1 mRNA have been made using a yeast artificial chromosome (YAC) containing the full-length human FMR1 gene. These YAC mice show a 2- to 3-fold increase in expression of FMR1 mRNA and a 10- to 15-fold increase in FMRP compared with control littermates $[42,43]$. When crossed with a knock-out (KO) mouse model of FXS that lacks FMRP, some of the pathological features of FXS were reversed. Importantly there were no changes in overall brain morphology at the light microscopic level due to overexpression of mRNA or protein. However, overexpression in otherwise WT mice (that is, not KO mice) also resulted in some abnormal behaviors, including decreased activity, increased anxiety-like behavior and enhanced startle response. Although the authors attributed these behavioral effects to overexpression of FMRP, the high levels of Fmr1 mRNA could also have contributed to the behavioral effects [43].

\section{Yeast artificial chromosome transgenic mouse models of the FPM}

YAC transgenic mouse lines have also been generated to study CGG repeat instability [44]. These mice were generated using a CGG92 allele isolated from an adult male premutation carrier, a CGG repeat length that would be expected to show expansion to the full mutation when transmitted through the female germ line in humans. The CGG92 region, including several hundred base pairs of flanking sequence, was cloned into a YAC and purified YAC DNA was injected into FVB/N mouse oocytes and then transplanted into foster mothers. A line of offspring (line TG296) carrying a CGG90 repeat were then identified. Although not yet well characterized, these YAC mice show modest intergenerational CGG repeat instability, expansion and contraction of one to three trinucleotides across generations. There was no influence of parental sex or age on transmission of the repeat. 


\section{New mouse models}

Continued development of new mouse models to study the FPM and FXTAS has resulted in generation of a doxycycline-inducible mouse line with a CGG99 repeat RNA under control of a doxycycline-responsive promoter (R. Hukema, Abstracts of the 1st Premutation Meeting, Perugia, Italy, 2013). Preliminary findings in this mouse show the presence of doxycycline-inducible ubiquitinpositive intranuclear inclusions in the hippocampus and cerebellum. This mouse is being used to determine critical periods for the onset of pathology as well as to help define molecular targets for development of future treatments.

\section{Brain and cellular pathology}

The description of brain pathology associated with FPM and FXTAS is limited by the availability of tissue for analysis. As a result, virtually all that is known about such pathology has come from studies of postmortem tissue from premutation carriers who developed FXTAS, and from findings in animal models. To date there have not been any published studies on brain pathology seen in FPM carriers without FXTAS, including if and when intranuclear inclusions and cell loss (for example, Purkinje neurons) may be occurring.

\section{Intranuclear inclusions}

The hallmark histopathology in FXTAS includes the presence of ubiquitin-positive inclusions in neurons and astrocytes that is widespread throughout the brain. As a further parallel between human FXTAS and the CGG KI mice, both show the presence of ubiquitin-positive intranuclear inclusions in many regions of the brain [24-26,45]. The CGG $_{\text {dut }}$ KI develops intranuclear inclusions in neurons in the cerebral cortex, olfactory nucleus, parafascicular thalamic nucleus, medial mammillary nucleus and colliculus inferior, cerebellum, amygdala and pontine nucleus cortex, hippocampus, hypothalamus, and in granule cells of the cerebellum (Figure 3) [24,28]. Inclusions in the dentate gyrus of the hippocampus are evident as early as 12 weeks of age [29]. The number of inclusions in glia, including astrocytes and Bergmann glia, and their distribution in the brain are more limited, and not as numerous as found in postmortem FXTAS brain tissue [14,25]. In addition, the size of the inclusions correlates significantly with the age of $\mathrm{CGG}_{\text {dut }}$ KI mice, with smaller inclusions found in younger mice. Interestingly, the gradual increase in the size of the inclusions and the percentage of ubiquitin-positive neurons appear to parallel the progressive development of the neurological phenotype of FXTAS in humans [16]. Brain regions showing the presence of intranuclear inclusions correlate with the clinical features in patients with symptomatic FXTAS. Importantly, inclusions are not limited to the nervous system, and are found in both human FXTAS and in the $\mathrm{CGG}_{\text {dut }}$
KI mouse in a variety of other tissues, including pancreatic, thyroid, adrenal gland, gastrointestinal, pituitary gland, pineal gland, heart and mitral valve. Inclusions were also found in the testes, epididymis and kidney of patients with FXTAS, but not in the KI mice [46]. Therefore, FXTAS should be considered a multi-organ disease. Systematic analysis of these inclusions shows the presence of more than 20 proteins including ubiquitin, molecular chaperone Hsp40, $20 \mathrm{~S}$ proteasome complex, DNA repair-ubiquitin-associated HR23B factor and SAM-68, DGCR8, and DROSHA [18,19,24,47-49]. The inclusions also contain FMR1 mRNA, but surprisingly not FMRP [18]. Similar studies on the protein composition of inclusions found in CGG mouse models have not been carried out, but it is already apparent that there are some similarities between the inclusions in FXTAS and mouse models, including the presence of ubiquitin, SAM68, DGCR8 and lamin A/C, as well as several differences $[18,19,24,27,47,50]$. Puro has been detected in intranuclear inclusions in a Drosophila model of the premutation and overexpression can suppress CGG repeat-mediated neurodegeneration. However, pura has not yet been detected in inclusions in murine models and evidence for its presence in human inclusions is inconclusive $[18,50]$. Similarly, hnRNP-A2/B1 are found in the intranuclear inclusions in FXTAS [18], but little or none has been found in CGG KI mice [34]. Additional research on the composition of intranuclear inclusions in FXTAS and mouse models would clearly be of value.

\section{Cell loss}

An important neuropathological finding in human FXTAS is the presence of Purkinje cell degeneration [35]. This has also been observed in the $\mathrm{CGG}_{\text {nih }}$ KI mouse, and in mice with an ectopic CGG90 repeat expansion whose expression is limited to cerebellar Purkinje neurons as shown in Figure 4 [26,34]. However, the generalized brain atrophy, including enlarged ventricles, that has been reported in some patients with FXTAS has not been systematically examined in any of the existing mouse models. Such studies need to be carried out using structural magnetic resonance imaging and quantitative stereology of neurons in brain regions known to be affected in FXTAS, to establish whether similar pathology also occurs in mouse models.

\section{White matter disease}

FXTAS is also characterized by white matter disease, including loss of glial cells, enlarged astrocytes, spongiosis and pallor in subcortical and cerebellar white matter, including in the middle cerebellar peduncle [14,35,51]. Additional pathology in FXTAS is seen on T2-weighted magnetic resonance images that show hyperintensities in white matter tracts, including the middle cerebellar peduncle [52]. Tractography studies using diffusion-weighted magnetic resonance imaging have provided additional 
evidence for degeneration in major white matter fibers tracts in FXTAS, including the middle cerebellar peduncle, superior cerebellar peduncle and corpus callosum, that was not found in premutation carriers without FXTAS [51]. As yet, these important findings have not been systematically examined in mouse models of the FPM or FXTAS, and there are no published reports of white matter pathology or degeneration of major fiber tracts in animal models.

\section{Dendrite and dendritic spine morphology}

Studies of Golgi-stained neurons have also revealed ultrastructural changes in dendrites and dendritic spines in both $\mathrm{CGG}_{\text {dut }}$ and $\mathrm{CGG}_{\text {nih }}$ KI mice [30,53]. The $\mathrm{CGG}_{\text {dut }} \mathrm{KI}$ mouse shows fewer dendritic branches proximal to the soma, reduced total dendritic length and longer dendritic spines on basilar, but not on apical dendrites in pyramidal neurons in the primary visual cortex. Neither total dendritic spine density, nor the density for specific dendritic spine subtypes (that is, stubby, mushroom, filipodial) differed between WT and KI mice. Dendrite and dendritic spine morphology has also been examined in $\mathrm{CGG}_{\text {nih }} \mathrm{KI}$ mice in several brain regions, including the medial prefrontal cortex, hippocampus and basal lateral amygdala. In all three brain regions, the branching complexity of apical and basilar dendrites was significantly lower and spines were longer in KI mice compared to WT, consistent with findings in the $\mathrm{CGG}_{\text {dut }} \mathrm{KI}$ mouse. However, in the $\mathrm{CGG}_{\text {nih }}$ KI mouse, dendritic spine density was generally increased in all three brain regions in contrast to the $\mathrm{CGG}_{\text {dut }} \mathrm{KI}$ mouse, which did not show changes in spine density. It is interesting to note that longer dendritic spines found in the cortex of CGG KI mice have also been reported in Golgi studies of postmortem tissue in FXS $[54,55]$ and in Fmr1 KO mice [56,57], whereas the reduction in dendritic branching complexity in CGG KI mice was not found in the Fmr1 KO mouse [56]. The reasons for these similarities and differences are unknown but should be further investigated. To our knowledge, dendritic branching and spine morphology have not been examined in postmortem tissues from carriers of the FPM or patients with FXTAS.

\section{Lamin A/C disruption}

Expression of expanded CGG RNA also results in the widespread disruption of lamin $\mathrm{A} / \mathrm{C}$ proteins with associated abnormalities in nuclear envelope morphology in vitro and in vivo [58,59]. Lamins $\mathrm{A} / \mathrm{C}$ are intermediate filament proteins that that line the inner nuclear membrane where they help maintain the shape and mechanical integrity of the nucleus [60]. They are generated from a single $L M N A$ gene by alternative splicing, and mutations have been linked to a variety of neurodegenerative diseases. Cells deficient in lamin A/C show decreased survival and defective response to DNA damage [61].
These observations suggest that FXTAS may result in a functional laminopathy. This is consistent with recent findings that demonstrate that laminopathy diseases, including restrictive dermopathy and Hutchinson-Gilford progeria syndrome, result in increased levels of reactive oxygen species and accumulation of DNA damage [62]. Moreover, several proteins involved in telomere maintenance [63-65] are present in the intranuclear inclusions characteristic of FXTAS (for example, lamin A/C, Ku80, $\gamma \mathrm{H} 2 \mathrm{AX}$ ) [18] and could account for shorter telomere length demonstrated in patients with FXTAS $[66,67]$. Shorter telomere length could also contribute to the reduce life expectancy associated with longer CGG repeat lengths in patients with FXTAS $[14,25]$. While disruption of nuclear lamin $\mathrm{A} / \mathrm{C}$ architecture has been reported in mouse embryonic fibroblasts from $\mathrm{CGG}_{\text {dut }}$ $\mathrm{KI}$ mice, studies in mice examining Ku80 and $\gamma \mathrm{H} 2 \mathrm{AX}$ have not been carried out [58].

\section{Mitochondrial dysfunction}

Several symptoms reported in FXTAS share some commonalities with mitochondrial respiratory chain enzyme deficiencies, including gait ataxia, white matter disease, peripheral neuropathology, muscular weakness and neuropsychiatric disorders [68]. Mitochondrial dysfunction occurs in FPM and FXTAS and has been examined in cultured skin fibroblasts and in frozen frontal cortex from postmortem brain tissue samples from premutation carriers with or without FXTAS [68]. Decreased NAD- and FAD-linked oxygen uptake rates have been found in premutation carriers compared to controls. In addition there is reduced expression of the mitochondrial protein MnSOD, an antioxidant enzyme, and nitration of ATPB, a putative marker for nitrative/oxidative stress is elevated approximately 2-fold in FPM and FXTAS compared to controls, indicating mitochondrial dysfunction. Mitochondrial dysfunction has also been found in cultured hippocampal neurons isolated from $\mathrm{CGG}_{\text {dut }} \mathrm{KI}$ mice as early as 4 days in vitro (DIV) [69]. Density and mobility were assessed by time-lapse imaging of mitochondria labeled with Mitotracker Red CMXRos, and oxygen consumption was estimated by measuring the rate of change of dissolved $\mathrm{O}_{2}$ in the medium surrounding the cultured hippocampal neurons using a Seahorse Bioscience extracellular flux analyzer. $\mathrm{CGG}_{\text {dut }}$ KI mice showed reduced density of mitochondria in proximal neurites (that is, within $25 \mu \mathrm{m}$ of soma), as well as significantly reduced mobility compared to WT mice. Neurons from $\mathrm{CGG}_{\text {dut }}$ KI mice also showed high basal oxygen consumption rates and evidence for increased protein leakage and higher ATP production. The authors suggested that these abnormalities in mitochondrial distribution and bioenergetics may contribute to previous reports of lower viability 
and reduced dendritic branching of cultured hippocampal neurons [70] as well as to reduced dendritic branching and altered spine morphology in CGG KI mouse neocortex [30,53]. It is important to consider the possibility that mitochondrial disease may contribute to the risk for premutation carriers to become symptomatic or to develop FXTAS, and this potential link should be explored in futures studies in using mouse models.

\section{Molecular findings \\ Fmr 1 mRNA and FMRP}

Both the $\mathrm{CGG}_{\text {dut }} \mathrm{KI}$ and the $\mathrm{CGG}_{\text {nih }} \mathrm{KI}$ mice have proven to be very useful models to study the molecular aspects of the expanded CGG repeat. The brains of these two mouse lines show small $(10 \%$ to $30 \%)$ to moderate $(>50 \%)$ reductions in FMRP, respectively, despite the fact that 2- to 3-fold elevated levels of Fmr1 mRNA are found $[23,26,28,71-73]$. These results parallel to a great extent what is found in some human premutation carriers and in patients with FXTAS as outlined in Table 1 [21]. The linear correlation between FMR1 mRNA levels and the repeat size in FPM and in patients with FXTAS $[72,74]$ has also been found in brain tissue from the $\mathrm{CGG}_{\text {dut }} \mathrm{KI}$ mouse [73]. Entezam et al. were able to show a direct relationship between CGG-CCG repeat size and Fmr1 mRNA levels in the brains of the $\mathrm{CGG}_{\text {nih }}$ KI mice, although the number of mice studied for the different repeat sizes was limited [26]. The cellular mechanism underlying the increase in Fmrl mRNA levels is unknown, but could be due to a feedback mechanism resulting from reduced levels of FMRP. Mechanisms underlying reduced FMRP include impeded migration of the $40 \mathrm{~S}$ ribosomal complex along the expanded CGG tract, as well as the use of an alternative internal ribosome entry site for initiation of translation. An internal ribosome entry site has been identified in the 5'UTR of FMR1 mRNA [75].

\section{Fmr1 splice variants and FMRP isoforms}

The FMR1 gene has 17 exons with alternative splice sites on exons 12, 14, 15 and 17 that result in the expression of multiple FMRP isoforms [76-78]. The splicing pattern of these isoforms is of interest as, in some isoforms, the truncation or absence of functional domains would suggest a change in FMRP functional properties including its selection of protein partners and mRNA targets and its cellular localization. For instance, the $\mathrm{N}$-terminus of FMRP harbors a nuclear localization signal and FMR1 mRNA binding activity is driven by two K Homology domains encoded by exons 8 to 12 and an RGG box domain in exons 14 to 15 [79]. Additionally, a nuclear export signal is localized to exon 14 and serine phosphorylation sites involved in translational regulatory activity of FMRP as well as methylation sites are also localized to exon 15 .
The transcript levels of these isoforms are developmentally regulated in the brain of the WT C57BL/6 mouse strain [77], the same strain used to construct the $\mathrm{CGG}_{\mathrm{dut}}$ KI mouse model [24]. Isoform distributions were similar across 11 different brain regions with the exception of the hippocampus and the olfactory bulb. Although to date no information is available on isoform distribution in the $\mathrm{CGG}_{\text {dut }} \mathrm{KI}$ mouse, the polyadenylation state of Fmrl transcripts, which can be informative for the stability and the translational efficiency of the mRNA, has been investigated in these mice. The $\mathrm{CGG}_{\text {dut }}$ KI mouse exhibits an increased population of short poly(A) mRNAs, usually indicative of inefficiently translated transcripts, compared to WT [80]. It would be interesting to know whether particular mRNA isoforms are thus more efficiently translated than others in the $\mathrm{CGG}_{\text {dut }}$ KI background.

\section{Expression profiling}

Dysfunction of the GABAergic system has been reported in $\mathrm{CGG}_{\text {dut }}$ KI mice [81]. Specifically, overexpression of genes for several $\mathrm{GABA}_{\mathrm{A}}$ receptor subunits (for example, $\alpha 1,3,4 ; \beta 2 ; \gamma 2)$ and proteins involved in GABA metabolism (gad1, ssadh) has been observed in the cerebellum, but not the cortex, of $\mathrm{CGG}_{\text {dut }}$ KI mice, which could be related to the motor phenotype observed in FXTAS $[82,83]$. In Fmr1 KO mice, expression was decreased for some of these same genes (for example, gad1, ssadh), but the reasons for this difference are unclear. Microarray analysis in the cerebellum of transgenic mice that overexpress human FMR1 with a normal range CGG29 repeat has also been carried out, but there were no clear changes in the GABAergic system compared to controls. Among GABArelated genes, only up-regulation of the $\mathrm{GABA}_{\mathrm{A}}$ receptorassociated protein-like 2 (Gabarapl2) gene was observed [41]. These results provide additional support that pathology in CGG KI mice, at least in the GABA system, is due to expansion of CGG repeats rather than increased mRNA levels, given that FMR1 mRNA levels were increased 20 to 100 times in these transgenic mice compared with those of WT littermates. However, other changes were seen in the transcriptome of these mice that could be a consequence of an overabundance of FMR1 mRNA. Interestingly, the two most altered genes in the transcriptome were transthyretin (Trt), and serpina3, putative biomarkers for Alzheimer's disease [84,85]. Serpina3, a serine protease inhibitor that is released during inflammatory responses, was up-regulated and may reflect the increased prevalence of autoimmune disease (for example, lupus, multiple sclerosis, fibromyalgia, thyroid disease) in females with the FMR1 premutation [86]. Transthyretin, a transport protein for retinol and thyroxine thought to contribute to thyroid hormone homeostasis, was down-regulated [87]. Although speculative, reduced transcription could be related to the hypothyroidism 
reported in some patients with FXTAS [3]. In addition, two microRNAs, mir-181a-1 and let-7 appeared upregulated in CGG mice. Up-regulation of Let-7 miRNA has been also been reported in a Drosophila model of FXTAS [88]. This is important because several miRNAs are up-regulated in human premutation carriers [89], although they differed from those observed in CGG transgenic mice [41].

\section{Electrophysiological findings \\ GABA/glutamate imbalance and abnormal synaptic network activity}

The origin of pathology in FXS and in some FPM carriers, with or without FXTAS mutations, is the presence of a CGG repeat expansion on FMR1, raising the possibility that some of the same molecular pathways could be affected in both disorders, and those associated with glutamatergic signaling in particular $[1,74,90,91]$. This is in spite of differences in the causal molecular underpinnings in the disorders, and specifically the lack of FMRP expression in FXS versus the overexpression of FMR1 mRNA in the FPM and FXTAS. In fact, the dysregulation in excitatory and inhibitory neurotransmission in the central nervous system of FXS $\mathrm{KO}$ mice has been the subject of active investigation during the last decade, and evidence has recently surfaced that suggests a similar dysregulation in the CGG KI mice [1,90,91].

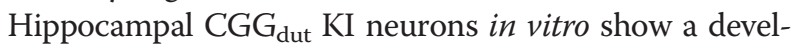
opmental defect in connectivity and impaired dendritic growth observed at 7 and 21 days DIV. There is also a loss of cell viability, also suggestive of a neurodegenerative component to the FPM [70]. Interestingly, in the same neurons, the expression of the vesicular GABA and glutamate transporters VGAT and VGLUR1, respectively, is reduced at $21 \mathrm{DIV}$, but not at $7 \mathrm{DIV}$. These alterations are associated with a 4- to 8-fold increase in Fmr1 mRNA and an approximately 50\% decrease in FMRP.

Abnormal patterns of electrical activity are also seen in vitro in hippocampal neurons from $\mathrm{CGG}_{\mathrm{dut}} \mathrm{KI}$ mice, including enhanced clustered burst (CB) firing. Specifically, hippocampal neurons cultured from $\mathrm{CGG}_{\text {dut }} \mathrm{KI}$ mice display $\mathrm{CB}$ electrical spiking activity and abnormal patterns of spontaneous synchronous $\mathrm{Ca}^{2+}$ oscillations under basal culture conditions [92]. The principal mechanisms contributing to these neuronal network defects in basal electrical activity appear to be associated with a gain of function in type I metabotropic glutamate receptors (mGluRs) and/or a loss of function in $\mathrm{GABA}_{\mathrm{A}}$ receptor signaling. This conclusion is supported by data indicating that: the type I mGluR receptor agonist 3,5-Dihydroxyphenylglycine (DHPG), but neither NMDA nor AMPA receptor agonists, increased CB firing patterns in WT neurons with increased spike rate and mean burst duration similar to those observed in FPM hippocampal neurons; selective mGluR1/5 antagonists 7-(hydroxyimino)cyclopropa[b]chromen-1a-carboxylate ethyl ester (CPCCOEt) and 2-methyl-6-(phenylethynyl) pyridine hydrochloride (MPEP) abrogated abnormal electrical activity in FPM neurons; FPM astrocytes have impaired glutamate uptake $[69,93]$; WT cultures exposed to the astrocyte glutamate transport competitive antagonist DL-threo- $\beta$-benzyloxyaspartic acid produced electrical firing patterns indistinguishable from those of $\mathrm{CGG}_{\text {dut }}$ KI neurons; $\mathrm{GABA}_{\mathrm{A}}$ receptor block with picrotoxin generated $\mathrm{CB}$ firing behavior observed in $\mathrm{CG}_{\mathrm{dut}}$ neurons; and the allosteric $\mathrm{GABA}_{\mathrm{A}}$ receptor enhancer allopregnanolone essentially restored WT electrical spiking patterns.

These functional deficits are directly pertinent to the altered patterns of neuronal complexity reported earlier using the same in vitro CGG $_{\text {dut }}$ KI model [70]. Neuronal network activity is essential for normal neuronal migration, dendritic growth and synaptic plasticity, processes mediated by spatially and temporally orchestrated intracellular $\mathrm{Ca}^{2+}$ signals. Therefore, the abnormal CB electrical activity and abnormal patterns of spontaneous $\mathrm{Ca}^{2+}$ oscillations observed in hippocampal neurons from $\mathrm{CGG}_{\text {dut }} \mathrm{KI}$ mice are likely to contribute, at least in part, to impaired dendritic growth and synaptic architecture.

\section{Hippocampal synaptic plasticity}

Deficits in processing spatial and temporal information have been reported in FPM carriers and in patients with FXTAS, suggesting hippocampal-associated pathology. In order to fully characterize the CGG KI mouse and to provide clues to which brain regions mediate these cognitive deficits (for example, hippocampus), in vitro studies of synaptic plasticity in acute hippocampal slices isolated from $\mathrm{CGG}_{\text {dut }}$ KI mice and WT mice have been carried out. Specifically long-term potentiation (LTP) of synaptic transmission and long-term synaptic depression (LTD) in CGG $_{\text {dut }}$ and WT mice have been examined. The results demonstrated that the magnitude of LTP was significantly lower in CGG KI mice compared to WT mice, indicating impaired synaptic plasticity. Similarly, LTD, whether induced by low-frequency electrical stimulation $(1 \mathrm{~Hz})$ or bath application of the mGluR1/5 agonist DHPG, was also limited in CGG KI mice versus WT mice. These findings implicate loss of neuroplasticity in the hippocampus in the spatial and temporal cognitive deficits associated with CGG repeat expansions and the neurological pathology in FXTAS [94]. By contrast, enhanced LTD has been reported in the $\mathrm{CGG}_{\text {nih }}$ KI mouse model [95]. LTD at CA3-CA1 hippocampal synapses induced by bath application of the group I mGluR agonist DHPG was enhanced relative to that seen in WT littermates. Fmr1 mRNA production was increased, FMRP translational efficiency in response to DHPG was impaired, and basal FMRP levels were 
moderately reduced. The authors noted that Fmr1 KO mice completely lacking FMRP also showed enhanced LTD, suggesting that the enhanced LTD in the $C_{\text {G }} G_{\text {nih }}$ KI mouse may be due, at least in part, to lower levels of FMRP. The differing results for LTD between the $\mathrm{CGG}_{\text {dut }}$ and $\mathrm{CGG}_{\text {nih }}$ KI mouse models may therefore be the result of small versus moderate reductions in FMRP, respectively, indicating different cellular mechanisms for the differing results.

\section{Developmental aspects in FPM and FXTAS}

FXTAS was originally described as a late-onset neurodegenerative disorder typically appearing in premutation carriers in the fifth or sixth decade of life. However, it is clear from both human $[96,97]$ and mouse studies [29] that the consequences of the expanded CGG repeat can be seen in FPM carriers much earlier in development, indicating that the disease process likely begins much earlier in life, and possibly as early as during gestation [98]. Some children with the premutation have been reported to show cognitive deficits and behavioral problems, including symptoms of autism spectrum disorder and attention-deficit hyperactivity disorder [96,97]. Young (<12-week-old) CGG $_{\text {dut }}$ and $\mathrm{CGG}_{\text {nih }}$ KI mice show impaired processing of spatial information [29] and abnormal locomotor activity and anxiety in the elevated Plus-maze [30].

The possibility that the premutation may affect early brain development is supported by findings in the $\mathrm{CGG}_{\text {dut }}$ KI mouse, where abnormal migration and differentiation of neuronal precursors during development of the embryonic cortical plate has been found [98]. In this study, precursor cells and embryonic neurons were labeled in utero on embryonic day 14 (E14) by intracerebral injections of a retrovirus encoding EGFP. The entire cell body, cytoplasm and processes of infected cells and their progeny were labeled with the EGFP reporter. The morphology of EGFP-labeled radial glial cells and immature neurons was not different between KI and WT neurons when examined on E17. However, there was evidence for altered differentiation of embryonic neural progenitor cells in the developing neocortex.

Radial glial cells in the ventricular zone express the transcription factor Pax6, divide at the ventricular surface and give rise to intermediate neuronal progenitor cells that express the transcription factor Tbr2 [99,100]. The $\mathrm{CGG}_{\text {dut }}$ KI mice had a greater number of Pax6 ${ }^{+}$cells in the ventricular zone and fewer $\mathrm{Tbr} 2^{+}$cells in the subventricular zone than WT mice, suggesting that delayed differentiation of the Pax6 cells in the CGG $_{\text {dut }}$ KI mice may have produced a shift towards more $\mathrm{Pax}^{+}$and fewer Tbr $2^{+}$cells. Importantly, the shift in cell distribution could not be attributed to increased proliferation of $\mathrm{Pax}^{+}$cells, decreased proliferation of $\mathrm{Tbr} 2^{+}$or increased cell death among $\mathrm{Tbr}^{+}$cells. These data suggest that the Fmr1 CGG repeat allele impacts the developing brain during gestation, much earlier than previously realized, and point to a neurodevelopmental component in FXTAS.

\section{Neurobehavioral correlates}

Key features of patients with FXTAS are late-onset ataxia and memory impairments. Similar phenotypes have been found for CGG KI mice. Motor performance on the rotarod declines with age in $\mathrm{CGG}_{\text {dut }} \mathrm{KI}$ mice [31]. In addition, sensory-motor coordination is impaired in adult $\mathrm{CGG}_{\text {dut }} \mathrm{KI}$ animals when they are required to traverse a horizontal ladder (the ladder rung task). Both male and female CGG $_{\text {dut }}$ KI mice showed impairments that were positively correlated with CGG repeat size [101]. Poor performance in the rotarod and ladder rung test may reflect the ataxia seen in FXTAS. Adult female CGG KI mice are also impaired in learning a skilled forelimb motor task, in which they are trained to reach through a narrow opening in a Plexiglas box to grasp and obtain a small food reward positioned just outside. Again, performance was worse with longer CGG repeat lengths [102]. Similar experiments have not yet been carried out in male mice. To date, studies in CGG KI mice have not reported intention tremors, a key neurological feature in FXTAS. The reason for this is unclear, but may be related to the quadrupedal organization of the rodent motor system.

Spatial learning and memory in the Morris water maze is impaired in CGG $_{\text {dut }}$ KI mice at 52 weeks of age, but not at 20 weeks, indicating a progressive nature of the deficit [31]. Additional spatial deficits in CGG $_{\text {dut }}$ KI mice are seen in the 'metric' spatial processing test, which involves processing precise angles and distances that separate objects in space, without regard to the identity of the objects [103]. In this test, mice are allowed to explore two identical objects separated in space by a fixed distance for $15 \mathrm{~min}$ (the study phase), showing very little further exploration at the end of this time. Mice are removed from the apparatus, the distance between the objects changed (for example, moved closer together), and the mice are allowed to re-explore the objects for $5 \mathrm{~min}$ (the test phase). During the test phase, WT mice showed increased object exploration, indicating that they detected a change in the distance between objects, whereas $\mathrm{CGG}_{\text {dut }} \mathrm{KI}$ mice failed to re-explore the objects. Deficits in this task were seen as early as 12 weeks of age, when small but easily detectable intranuclear inclusions were present in neurons in the dentate gyrus of the hippocampus but not in the parietal cortex [29]. Lesion studies have implicated the dentate gyrus and CA3 hippocampus in processing of metric spatial information, a form of spatial pattern separation [104]. This suggests that histopathology (for example, presence of intranuclear inclusions, altered dendritic and spine morphology) in the dentate gyrus and CA3 subregion of the hippocampus in 
CGG KI mice may contribute to this spatial processing deficit. Although the role of intranuclear inclusions to pathology in FXTAS is unclear, the presence of intranuclear inclusions in different brain regions at different ages appears to follow a similar time course as the emergence of behavioral dysfunction in the CGG KI mouse, suggesting there might be a relationship between spatial deficits and inclusion formation $[24,105,106]$.

Additional behavioral pathology found in the $\mathrm{CGG}_{\text {nih }}$ KI mouse model of the FPM and FXTAS includes mild hyperactivity, decreased anxiety in elevated plus maze, and impaired shock avoidance learning [30].

\section{Evidence for current disease models RNA toxicity}

Studies in mouse models have been particularly useful in identifying molecular mechanisms in the FPM and FXTAS. An RNA 'toxic gain of function' mechanism has been proposed in which elevated FMR1 mRNA transcripts bearing an expanded CGG repeat are cytotoxic. Toxicity appears to be the result of the expanded CGG repeat per se, and not of overexpression of FMR1. This is supported by the fact that ectopic expression of a CGG repeat expansion in the premutation range is sufficient to induce formation of intranuclear inclusions, reduce cell viability, trigger neuronal death (for example, Purkinje cell loss) and produce behavioral deficits [34,59,107], whereas overexpression of Fmr1 mRNA without a CGG repeat expansion does not appear to be toxic [41]. Similar RNA toxicity has been suggested to underlie the pathology in several repeat diseases, including the myotonic muscular dystrophies. In this model, sequestration of important proteins through their interactions with expanded repeats prevents the proteins from carrying out their normal functions. As shown in Figure 2A, a similar protein sequestration mechanism has been proposed to underlie disease processes in the FPM and in FXTAS $[2,36,82,108]$. Based on studies in human and animal (for example, mouse, fly) tissues, a number of candidate RNA binding proteins have been identified, including DGCR8 and DROSHA [47], SAM68 [19], pura [109,110], hnRNPA2/B1 and CUGBP1 [37].

\section{Sequestration of DROSHA/DGCR8 and miRNAs}

While the evidence is strong for the binding of proteins to CGG expansions and sequestration of proteins within ubiquitin-positive inclusions, the consequences of sequestration for cell function remain to be described. However, a recent study has linked sequestration of proteins associated with miRNA processing with the disease process in FXTAS [47]. Specifically, the double-stranded RNAbinding protein DGCR8 binds preferentially to CGG repeats of pathogenic length (that is, CGG repeat length $>60$ ). As depicted in Figure 2A, this leads to partial sequestration of DGCR8 and its binding partner DROSHA to expanded CGG repeats within CGG RNA aggregates. DGCR8 and DROSHA are important for processing pre-miRNAs into mature miRNAs by the DICER enzyme. Dgcr8 deficiency in heterozygous Dgcr8+/- mice results in reduced synaptic potentiation in layer five pyramidal neurons in the medial prefrontal cortex of mice [111]. Large deletions in the 22q11 locus, which include Dgcr8, result in altered dendritic spine morphology, reduced dendritic branching complexity and impaired working memory [112]. Similarly, loss of DICER in mice results in progressive neuronal degeneration [113], reduced dendritic branching and increased dendritic spine length [114], ataxia, and reduced brain size following deletion from striatal neurons [115]. These results suggested a model in which double-stranded CGG RNA forms hairpins [91] that mimic the RNA structure of pre-miRNAs recognized by DGCR8 [47]. DGCR8 and its partner DROSHA bind to the expanded CGG repeat element and are therefore sequestered, reducing the production of mature miRNAs causing neuronal dysfunction and death [47]. This possibility is supported by the observation that the expression of mature miRNAs was decreased in postmortem brain samples from patients with FXTAS. In addition, in vitro overexpression of DGCR8 restored normal dendritic growth and branching, and alleviated cell death of cultured neurons expressing a toxic 60 CGG repeat [47].

\section{Repeat associated non-AUG translation}

An additional mechanism of toxicity is shown in Figure 2B. In this model, toxicity is triggered by CGG RAN translation [20]. This is based on evidence that trinucleotide repeats can be translated into protein even if they do not reside in an AUG-initiated open reading frame [116], and such translation can occur in all three possible open reading frames of a transcript generating multiple potentially toxic products from a single repeat [117]. In the case of FXTAS, it has been proposed that RAN translation initiated in the 5'UTR of FMR1 mRNA results in the production of a cytotoxic polyglycine-containing protein named FMRpolyG [20]. This is supported by results from human FXTAS and animal model studies. Specifically, the presence of the FMRpolyG was confirmed by western blot in cerebellar lysates of postmortem FXTAS brains. FMRpolyG staining was specific for FXTAS, and was not found in control brains, or in brain sections from patients with spinocerebellar ataxia type 3 or Alzheimer's disease. Interestingly, there were clear differences between the $\mathrm{CGG}_{\text {dut }} \mathrm{KI}$ and $\mathrm{CGG}_{\text {nih }}$ KI mouse models, with co-localization of FMRpolyG and ubiquitin-positive intranuclear inclusions in the cortex and hypothalamus of the CGG $_{\text {dut }}$ KI mouse, but not in the $\mathrm{CGG}_{\text {nih }} \mathrm{KI}$ mouse. These data suggest that some of the differing pathology between the two mouse 
models could be explained by differences in the ability to generate the toxic polyglycine peptide. The mechanisms underlying RAN translation are as yet unknown, but the presence of the polyglycine peptide (that is, FMRpolyG) in FXTAS and the CGG KI mouse models led to the proposal by Todd et al. that a scanning $43 \mathrm{~S}$ ribosomal pre-initiation complex stalls at the CGG repeat, resulting in use of an alternative non-AUG start site for translation in the +1 reading frame (that is, GGC, polyglycine) and the production of the FMRpolyG protein. The data did not show translation product from the +0 (that is, CGG, polyarginine) reading frame, but some, albeit less efficient, translation in the +2 (that is, GCG, polyalanine) reading frame was observed [20].

\section{Conclusions}

Although uniquely human components of disease cannot be fully captured in other species, mouse models of FXTAS have provided useful research tools to test hypotheses about the causes of the disorder, and to discover effective treatments. Development of CGG KI mice has provided insight into the natural history of the disorder, the molecular correlates, hallmark pathology in the brain and other organ systems, as well as an understanding of the neurobehavioral effects of expression of CGG repeat expansions. These KI mice now allow for the evaluation of novel therapeutic strategies, whether pharmacological or gene-targeted, to halt or reverse disease processes and to improve neurological outcome. Ongoing development of new mouse lines, including conditional and inducible mice, should further increase the value of animal models to understand the pathology of repeat disorders such as FXTAS. There are many open questions to be answered that will continue to rely on mouse models, including why mRNA levels are elevated, the importance of reduced FMRP in pathology, whether intranuclear inclusions are toxic or simply mark the progress of disease, and how protein sequestration and RAN translation contribute to the disease process in FPM and FXTAS.

\footnotetext{
Abbreviations

AMPA: a-amino-3-hydroxy-5-methyl-4-isoxazole propionic acid; ATPB: $\beta$-subunit of ATP synthase; CB: clustered burst; DHPG: 3,5-dihydroxyphenylglycine; DIV: days in vitro; EGFP: enhanced green fluorescent protein; FAD: flavin adenine dinucleotide; FMRP: fragile $X$ mental retardation protein; FPM: fragile $X$ premutation; FXS: fragile X syndrome; FXTAS: fragile X-associated tremor/ataxia syndrome; Kl: knock-in; KO: knock-out; LTD: long-term synaptic depression; mGluR: metabotropic glutamate receptors; miRNA: microRNA; MnSOD: manganese superoxide dismutase; NMDA: N-methyl-d-aspartate; NAD: nicotinamide adenine dinucleotide; UTR: untranslated region; WT: wild-type; YAC: yeast artificial chromosome.
}

\section{Competing interests}

DLN patented a method for detecting FMR1 mutation: US PTO 6,107,015 diagnosis of the fragile $x$ syndrome. All other authors declare that they have no competing interests.

\section{Authors' contributions}

All of the authors contributed to the conceptualization and the writing of this review. All authors read and approved the final manuscript.

\section{Acknowledgements}

The assistance of Andreea Pop with the editing of this manuscript is appreciated. The following funding sources supported the writing of this manuscript: NS079775 (RFB, RW); NICHD P30 HD24064-15 S1 (DLN); Dutch Brain Foundation (RW); the Intramural Program of NIDDK, NIH (KU), NIEHS ES011269 and DOD PR120921(INP); E-Rare grant (RKH); Belgian National Fund for Scientific Research, Flanders (RFK), Ministry of Health, Spain (EP).

\section{Author details}

${ }^{1}$ Department of Neurological Surgery, Room 502C, UC Davis, 1515 Newton Court, Davis, CA 95618, USA. ²Department Clinical Genetics, Erasmus MC, Rotterdam, Netherlands. ${ }^{3} \mathrm{NIDDK}$, National Institutes of Health, Bethesda, MD, USA. ${ }^{4}$ University of Seville, School of Medicine, Seville, Spain. ${ }^{5}$ Department of Medical Genetics, University of Antwerp, Antwerp, Belgium. ${ }^{6}$ UC Davis M.I.N. D. Institute, Sacramento, CA, USA. ${ }^{7}$ Department Molecular Biosciences, UC Davis, Davis, CA, USA. ${ }^{8}$ Department of Molecular and Human Genetics, Baylor College of Medicine, Houston, TX, USA. ${ }^{9}$ Department of Translational Medicine, IGBMC, Illkirch, France.

Received: 22 October 2013 Accepted: 29 January 2014

Published: 30 July 2014

\section{References}

1. Bear MF, Huber KM, Warren ST: The mGluR theory of fragile $X$ mental retardation. Trends Neurosci 2004, 27:370-377.

2. Renoux AJ, Todd PK: Neurodegeneration the RNA way. Prog Neurobiol 2012, 97:173-189.

3. Hagerman R, Hagerman P: Advances in clinical and molecular understanding of the FMR1 premutation and fragile $\mathrm{X}$-associated tremor/ataxia syndrome. Lancet Neurol 2013, 12:786-798.

4. Verkerk AJ, Pieretti M, Sutcliffe JS, Fu YH, Kuhl DP, Pizzuti A, Reiner O, Richards S, Victoria MF, Zhang FP, Eussen BE, van Ommen GJB, Blonden LAJ, Riggins GJ, Chastain JL, Knust CB, Galijaard H, Caskey CT, Nelson DL, Oostra BA, Warren ST: Identification of a gene (FMR-1) containing a CGG repeat coincident with a breakpoint cluster region exhibiting length variation in fragile X syndrome. Cell 1991, 65:905-914.

5. Willemsen R, Levenga J, Oostra B: CGG repeat in the FMR1 gene: size matters. Clin Genet 2011, 80:214-225.

6. Hantash FM, Goos DM, Crossley B, Anderson B, Zhang K, Sun W, Strom CM: FMR1 premutation carrier frequency in patients undergoing routine population-based carrier screening: insights into the prevalence of fragile $X$ syndrome, fragile $X$-associated tremor/ataxia syndrome, and fragile $X$-associated primary ovarian insufficiency in the United States. Genet Med 2011, 13:39-45.

7. Tassone T, Long KP, Tong T-H, Lo J, Gane LW, Berry-Kravis E, Nguyen D, Mu LY, Laffin J, Bailey DB, Hagerman RJ: FMR1 CGG allele size and prevalence ascentained through newborn screening in the United States. Genome Med 2012, 4:100.

8. Yu S, Pritchard M, Kremer E, Lynch M, Nancarrow J, Baker E, Holman K, Mulley JC, Warren ST, Schlessinger D, Sutherland GR, Richards RI: Fragile X genotype characterized by an unstable region of DNA. Science 1991, 252:1179-1181.

9. Hagerman FJ, Hagerman PJ: The fragile $X$ premutation: into the phenotypic fold. Curr Opin Genet Dev 2002, 12:278-283.

10. Grigsby J, Brega AG, Engle K, Leehey MA, Hagerman RJ, Tassone F, Hessl D, Hagerman PJ, Cogswell JB, Bennett RE, Cook K, Hall DA, Bounds LS, Paulich MJ, Reynolds A: Cognitive profile of fragile $X$ premutation carriers with and without fragile X-associated tremor/ataxia syndrome. Neuropsychology 2008, 22:48-60.

11. Kim SY, Hashimoto RI, Tassone F, Simon TJ, Rivera SM: Altered neural activity of magnitude estimation processing in adults with the fragile $X$ premutation. J Psychiatr Res 2013, 47:1909-1916.

12. Berry-Kravis E, Abrams L, Coffey SM, Hall DA, Greco C, Gane LW, Grigsby J, Bourgeois JA, Finucane B, Jacquemont S, Brunberg JA, Zhang L, Lin J, Tassone F, Hagerman PJ, Hagerman RJ, Leehey MA: Fragile X-associated tremor/ataxia syndrome: clinical features, genetics, and testing guidelines. Mov Disord 2007, 22:2018-2030. quiz 2140. 
13. Hagerman PJ, Hagerman RJ: Fragile X-associated tremor/ataxia syndrome (FXTAS). Ment Retard Dev Disabil Res Rev 2004, 10:25-30.

14. Greco CM, Berman RF, Martin RM, Tassone F, Schwartz PH, Chang A, Trapp BD, Iwahashi C, Brunberg J, Grigsby J, HessI D, Becker EJ, Papazian J, Leehey MA, Hagerman RJ, Hagerman PJ: Neuropathology of fragile X-associated tremor/ataxia syndrome (FXTAS). Brain 2006, 129:243-255.

15. Rodriguez-Revenga L, Madrigal I, Pagonabarraga J, Xuncla M, Badenas C, Kulisevsky J, Gomez B, Mila M: Penetrance of FMR1 premutation associated pathologies in fragile $X$ syndrome families. Eur J Hum Genet 2009, 17:1359-1362.

16. Jacquemont S, Farzin F, Hall D, Leehey M, Tassone F, Gane L, Zhang L, Grigsby J, Jardini T, Lewin F, Berry-Kravis E, Hagerman PJ, Hagerman RJ: Aging in individuals with the FMR1 mutation. Am J Ment Retard 2004, 109:154-164.

17. Iwahashi C, Hagerman PJ: Isolation of pathology-associated intranuclear inclusions. Methods Mol Biol 2008, 463:181-190.

18. Iwahashi $\mathrm{CK}$, Yasui $\mathrm{DH}$, An HJ, Greco CM, Tassone F, Nannen K, Babineau B, Lebrilla CB, Hagerman RJ, Hagerman PJ: Protein composition of the intranuclear inclusions of FXTAS. Brain 2006, 129:256-271.

19. Sellier C, Rau F, Liu Y, Tassone F, Hukema RK, Gattoni R, Schneider A, Richard S, Willemsen R, Elliott DJ, Hagerman PJ, Charlet-Berguerand N: Sam68 sequestration and partial loss of function are associated with splicing alterations in FXTAS patients. EMBO J 2010, 29:1248-1261.

20. Todd PK, Oh SY, Krans A, He F, Sellier C, Frazer M, Renoux AJ, Chen KC, Scaglione KM, Basrur V, Elenitoba-Johnson K, Vonsattel JP, Louis ED, Sutton MA, Taylor JP, Mills RE, Charlet-Berguerand N, Paulson HL: CGG repeat-associated translation mediates neurodegeneration in fragile $\mathrm{X}$ tremor ataxia syndrome. Neuron 2013, 78:440-455.

21. Berman RF, Willemsen R: Mouse models of fragile $x$-associated tremor ataxia. J Investig Med 2009, 57:837-841.

22. Bontekoe CJ, Bakker CE, Nieuwenhuizen IM, van Der Linde H, Lans $H$, de Lange D, Hirst MC, Oostra BA: Instability of a (CGG)(98) repeat in the Fmr1 promoter. Hum Mol Genet 2001, 10:1693-1699.

23. Brouwer JR, Mientjes EJ, Bakker CE, Nieuwenhuizen IM, Severijnen LA, Van der Linde HC, Nelson DL, Oostra BA, Willemsen R: Elevated Fmr1 mRNA levels and reduced protein expression in a mouse model with an unmethylated fragile X full mutation. Exp Cell Res 2007, 313:244-253.

24. Willemsen R, Hoogeveen-Westerveld M, Reis S, Holstege J, Severijnen LA, Nieuwenhuizen IM, Schrier M, van Unen L, Tassone F, Hoogeveen AT, Hagerman PJ, Mientjes EJ, Oostra BA: The FMR1 CGG repeat mouse displays ubiquitin-positive intranuclear neuronal inclusions; implications for the cerebellar tremor/ataxia syndrome. Hum Mol Genet 2003, 12:949-959.

25. Wenzel HJ, Hunsaker MR, Greco CM, Willemsen R, Berman RF: Ubiquitin-positive intranuclear inclusions in neuronal and glial cells in a mouse model of the fragile X premutation. Brain Res 2010, 1318:155-166.

26. Entezam A, Biacsi R, Orrison B, Saha T, Hoffman GE, Grabczyk E, Nussbaum RL, Usdin K: Regional FMRP deficits and large repeat expansions into the full mutation range in a new fragile X premutation mouse model. Gene 2007, 395:125-134.

27. Hoffman GE, Le WW, Entezam A, Otsuka N, Tong Z-B, Nelson L, Flaws JA McDonald JH, Jafar S, Usdin K: Ovarian abnormalities in a mouse model of fragile x primary ovarian insufficiency. J Histochem Cytochem 2012, 60:439-456.

28. Brouwer JR, Huizer K, Severijnen LA, Hukema RK, Berman RF, Oostra BA, Willemsen R: CGG-repeat length and neuropathological and molecular correlates in a mouse model for fragile $\mathrm{X}$-associated tremor/ataxia syndrome. J Neurochem 2008, 107:1671-1682.

29. Hunsaker MR, Wenzel HJ, Willemsen R, Berman RF: Progressive spatial processing deficits in a mouse model of the fragile $\mathrm{X}$ premutation. Behav Neurosci 2009, 123:1315-1324.

30. Qin M, Entezam A, Usdin K, Huang T, Liu ZH, Hoffman GE, Smith CB: A mouse model of the fragile $X$ premutation: effects on behavior, dendrite morphology, and regional rates of cerebral protein synthesis. Neurobiol Dis 2011, 42:85-98.

31. Van Dam D, Errijgers V, Kooy RF, Willemsen R, Mientjes E, Oostra BA, de Deyn PP: Cognitive decline, neuromotor and behavioural disturbances in a mouse model for fragile-X-associated tremor/ataxia syndrome (FXTAS). Behav Brain Res 2005, 162:233-239.

32. Entezam A, Usdin K: ATR protects the genome against CGG.CCG-repeat expansion in fragile X premutation mice. Nucleic Acids Res 2008, 36:1050-1056.
33. Lokanga RA, Entezam A, Kumari D, Yudkin D, Qin M, Smith CB, Usdin K: Somatic expansion in mouse and human carriers of fragile $X$ premutation alleles. Hum Mutat 2013, 34:157-166.

34. Hashem V, Galloway JN, Mori M, Willemsen R, Oostra BA, Paylor R, Nelson $D L$ : Ectopic expression of CGG containing mRNA is neurotoxic in mammals. Hum Mol Genet 2009, 18:2443-2451.

35. Greco CM, Hagerman RJ, Tassone F, Chudley AE, Del Bigio MR, Jacquemont S, Leehey M, Hagerman PJ: Neuronal intranuclear inclusions in a new cerebellar tremor/ataxia syndrome among fragile X carriers. Brain 2002, 125:1760-1771.

36. Jin P, Zarnescu DC, Zhang F, Pearson CE, Lucchesi JC, Moses K, Warren ST: RNA-mediated neurodegeneration caused by the fragile $X$ premutation rCGG repeats in Drosophila. Neuron 2003, 39:739-747.

37. Sofola OA, Jin P, Qin Y, Duan R, Liu H, de Haro M, Nelson DL, Botas J: RNA-binding proteins hnRNP A2/B1 and CUGBP1 suppress fragile X CGG premutation repeat-induced neurodegeneration in a Drosophila model of FXTAS. Neuron 2007, 55:565-571.

38. Timchenko LT, Miller JW, Timchenko NA, DeVore DR, Datar KV, Lin L, Roberts R, Caskey CT, Swanson MS: Identification of a (CUG)n triplet repeat RNA-binding protein and its expression in myotonic dystrophy. Nucleic Acids Res 1996, 24:4407-4414.

39. Timchenko NA, lakova P, Cai ZJ, Smith JR, Timchenko LT: Molecular basis for impaired muscle differentiation in myotonic dystrophy. Mol Cell Biol 2001, 21:6927-6938.

40. Charizanis K, Lee KY, Batra R, Goodwin M, Zhang C, Yuan Y, Shiue L, Cline M, Scotti MM, Xia G, Kumar A, Ashizawa T, Clark HB, Kimura T, Takahashi MP, Fujimura H, Jinnai K, Yoshikawa H, Gomes-Pereira M, Gourdon G, Sakai N, Nishino S, Foster TC, Ares M Jr, Darnell RB, Swanson MS: Muscleblind-like 2-mediated alternative splicing in the developing brain and dysregulation in myotonic dystrophy. Neuron 2012, 75:437-450.

41. Fernandez JJ, Martinez R, Andujar E, Perez-Alegre M, Costa A, Bonilla-Henao V, Sobrino F, Pintado CO, Pintado E: Gene expression profiles in the cerebellum of transgenic mice over expressing the human FMR1 gene with CGG repeats in the normal range. Genet Mol Res 2012, 11:467-483.

42. Peier AM, Mcllwain KL, Kenneson A, Warren ST, Paylor R, Nelson DL: (Over) correction of FMR1 deficiency with YAC transgenics: behavioral and physical features. Hum Mol Genet 2000, 9:1145-1159.

43. Spencer CM, Graham DF, Yuva-Paylor LA, Nelson DL, Paylor R: Social behavior in Fmr1 knockout mice carrying a human FMR1 transgene. Behav Neurosci 2008, 122:710-715.

44. Peier AM, Nelson DL: Instability of a premutation-sized CGG repeat in FMR1 YAC transgenic mice. Genomics 2002, 80:423-432.

45. Schluter EW, Hunsaker MR, Greco CM, Willemsen R, Berman RF: Distribution and frequency of intranuclear inclusions in female CGG $\mathrm{KI}$ mice modeling the fragile $\mathrm{X}$ premutation. Brain Res 2012, 1472:124-137.

46. Hunsaker MR, Greco CM, Spath MA, Smits AP, Navarro CS, Tassone F, Kros JM, Severijnen LA, Berry-Kravis EM, Berman RF, Gane LW, Jacquemont S, Basuta K, Jin LW, Hagerman PJ, Hagerman RJ: Widespread non-central nervous system organ pathology in fragile $X$ premutation carriers with fragile $X$-associated tremor/ataxia syndrome and CGG knock-in mice. Acta Neuropathol 2011, 122:467-479.

47. Sellier C, Freyermuth F, Tabet R, Tran T, He F, Ruffenach F, Alunni V, Moine $H$, Thibault C, Page A, Tassone F, Willemsen R, Disney MD, Hagerman PJ, Todd PI Charlet-Berguerand N: Sequestration of DROSHA and DGCR8 by expanded CGG RNA repeats alters MicroRNA processing in fragile X-associated tremor/ataxia syndrome. Cell Reprogram 2013, 3:869-880.

48. Tassone F, Hagerman RJ, Garcia-Arocena D, Khandjian EW, Greco CM, Hagerman $P J$ : Intranuclear inclusions in neural cells with premutation alleles in fragile $X$ associated tremor/ataxia syndrome. J Med Genet 2004, 41:e43.

49. Bergink S, Severijnen LA, Wijgers N, Sugasawa K, Yousaf H, Kros JM, van Swieten J, Oostra BA, Hoeijmakers JH, Vermeulen W, Willemsen R: The DNA repair-ubiquitin-associated HR23 proteins are constituents of neuronal inclusions in specific neurodegenerative disorders without hampering DNA repair. Neurobiol Dis 2006, 23:708-716.

50. Galloway JN, Nelson DL: Evidence for RNA-mediated toxicity in the fragile X-associated tremor/ataxia syndrome. Future Neurol 2009, 4:785.

51. Wang JY, Hessl D, Schneider A, Tassone F, Hagerman RJ, Rivera SM: Fragile $\mathrm{X}$-associated tremor/ataxia syndrome: influence of the FMR1 gene on motor fiber tracts in males with normal and premutation alleles. JAMA Neurol 2013, 70:1022-1029. 
52. Brunberg JA, Jacquemont S, Hagerman RJ, Berry-Kravis EM, Grigsby J, Leehey MA, Tassone F, Brown WT, Greco CM, Hagerman PJ: Fragile X premutation carriers: characteristic MR imaging findings of adult male patients with progressive cerebellar and cognitive dysfunction. AJNR Am J Neuroradiol 2002, 23:1757-1766.

53. Berman RF, Murray KD, Arque G, Hunsaker MR, Wenzel HJ: Abnormal dendrite and spine morphology in primary visual cortex in the CGG knock-in mouse model of the fragile X premutation. Epilepsia 2012, 53(Suppl 1):150-160.

54. Hinton VJ, Brown WT, Wisniewski K, Rudelli RD: Analysis of neocortex in three males with the fragile X syndrome. Am J Med Genet 1991, 41:289-294.

55. Irwin SA, Patel B, Idupulapati M, Harris JB, Crisostomo RA, Larsen BP, Kooy F, Willems PJ, Cras P, Kozlowski PB, Swain RA, Weiler IJ, Greenough WT: Abnormal dendritic spine characteristics in the temporal and visual cortices of patients with fragile- $X$ syndrome: a quantitative examination. Am J Med Genet 2001, 98:161-167.

56. Irwin SA, Idupulapati M, Gilbert ME, Harris JB, Chakravarti AB, Rogers EJ, Crisostomo RA, Larsen BP, Mehta A, Alcantara CJ, Patel B, Swain RA, Weiler IJ, Oostra BA, Greenough WT: Dendritic spine and dendritic field characteristics of layer $\mathrm{V}$ pyramidal neurons in the visual cortex of fragile-X knockout mice. Am J Med Genet 2002, 111:140-146.

57. McKinney BC, Grossman AW, Elisseou NM, Greenough WT: Dendritic spine abnormalities in the occipital cortex of C57BL/6 Fmr1 knockout mice. Am J Med Genet B Neuropsychiatr Genet 2005, 136B:98-102.

58. Garcia-Arocena D, Yang JE, Brouwer JR, Tassone F, Iwahashi C, Berry-Kravis EM, Goetz CG, Sumis AM, Zhou L, Nguyen DV, Campos L, Howell E, Ludwig A, Greco C, Willemsen R, Hagerman RJ, Hagerman PJ: Fibroblast phenotype in male carriers of FMR1 premutation alleles. Hum Mol Genet 2010, 19:299-312.

59. Arocena DG, Iwahashi CK, Won N, Beilina A, Ludwig AL, Tassone F, Schwartz PH, Hagerman PJ: Induction of inclusion formation and disruption of lamin A/C structure by premutation CGG-repeat RNA in human cultured neural cells. Hum Mol Genet 2005, 14:3661-3671.

60. Lammerding J, Fong LG, Ji JY, Reue K, Stewart CL, Young SG, Lee RT: Lamins $\mathrm{A}$ and $\mathrm{C}$ but not lamin $\mathrm{B} 1$ regulate nuclear mechanics. J Biol Chem 2006, 281:25768-25780.

61. Singh M, Hunt CR, Pandita RK, Kumar R, Yang CR, Horikoshi N, Bachoo R, Serag S, Story MD, Shay JW, Shay JW, Powell SN, Gupta A, Jeffery J, Pandita S, Chen BP, Deckbar D, Lobrich M, Yang Q, Khanna KK, Worman HJ, Pandita TK: Lamin A/C depletion enhances DNA damage-induced stalled replication fork arrest. Mol Cell Biol 2013, 33:1210-1222.

62. Richards SA, Muter J, Ritchie P, Lattanzi G, Hutchison CJ: The accumulation of un-repairable DNA damage in laminopathy progeria fibroblasts is caused by ROS generation and is prevented by treatment with $\mathrm{N}$-acetyl cysteine. Hum Mol Genet 2011, 20:3997-4004.

63. Blasco MA: Telomeres and human disease: ageing, cancer and beyond. Nat Rev Genet 2005, 6:611-622.

64. Cao K, Blair CD, Faddah DA, Kieckhaefer JE, Olive M, Erdos MR, Nabel EG, Collins FS: Progerin and telomere dysfunction collaborate to trigger cellular senescence in normal human fibroblasts. J Clin Invest 2011, 121:2833-2844.

65. Gonzalez-Suarez I, Redwood AB, Perkins SM, Vermolen B, Lichtensztejin D, Grotsky DA, Morgado-Palacin L, Gapud EJ, Sleckman BP, Sullivan T, Sage J, Stewart CL, Mai S, Gonzalo S: Novel roles for A-type lamins in telomere biology and the DNA damage response pathway. EMBO J 2009, 28:2414-2427.

66. Garcia-Arocena D, Hagerman PJ: Advances in understanding the molecular basis of FXTAS. Hum Mol Genet 2010, 19:R83-R89.

67. Jenkins EC, Tassone F, Ye L, Gu H, Xi M, Velinov M, Brown WT, Hagerman RJ, Hagerman PJ: Reduced telomere length in older men with premutation alleles of the fragile $X$ mental retardation 1 gene. Am J Med Genet A 2008, 146A:1543-1546.

68. Ross-Inta C, Omanska-Klusek A, Wong S, Barrow C, Garcia-Arocena D, Iwahashi C, Berry-Kravis E, Hagerman RJ, Hagerman PJ, Giulivi C: Evidence of mitochondrial dysfunction in fragile $\mathrm{X}$-associated tremor/ataxia syndrome. Biochem J 2010, 429:545-552.

69. Kaplan ES, Cao Z, Hulsizer S, Tassone F, Berman RF, Hagerman PJ, Pessah IN: Early mitochondrial abnormalities in hippocampal neurons cultured from Fmr1 pre-mutation mouse model. J Neurochem 2012, 123:613-621.

70. Chen Y, Tassone F, Berman RF, Hagerman PM, Hagerman RJ, Willemsen R, Pessah IN: Murine hippocampal neurons expressing Fmr1 gene premutation show early developmental deficits and late degeneration. Hum Mol Genet 2010, 19:196-208.

71. Willemsen R, Li Y, Berman RF, Brouwer JR, Oostra VA, Jin P: Animal models of FXTAS. In The Fragile X-Associated Tremor Ataxia. Edited by Tassone F, Berry-Kravis EM. New York: Springer Science; 2010:123-136.

72. Kenneson A, Zhang F, Hagedorn CH, Warren ST: Reduced FMRP and increased FMR1 transcription is proportionally associated with CGG repeat number in intermediate-length and premutation carriers. Hum Mol Genet 2001, 10:1449-1454.

73. Ludwig AL, Espinal GM, Pretto DI, Jamal AL, Arque G, Tassone F, Berman RF, Hagerman PJ: CNS expression of murine fragile $X$ protein (FMRP) as a function of CGG-repeat size. Hum Mol Genet 2014. Epub ahead of print doi:10.1093/hmg/ddu032.

74. Pretto DL, Kumar M, Cao Z, Cunningham CL, Durbin-Johnson B, Qi L, Berman RF, Noctor SC, Hagerman RJ, Pessah IN, Tassone F: Reduced EAAT1 and mGluR5 expression in the cerebellum of Fmr1 premutation carriers with FXTAS. Neurobiol Aging 2014, 35:1189-1197.

75. Chiang PW, Carpenter LE, Hagerman PJ: The 5'-untranslated region of the FMR1 message facilitates translation by internal ribosome entry. J Biol Chem 2001, 276:37916-37921.

76. Ashley CT, Sutcliffe JS, Kunst CB, Leiner HA, Eichler EE, Nelson DL, Warren ST: Human and murine FMR-1: alternative splicing and translational initiation downstream of the CGG-repeat. Nat Genet 1993, 4:244-251.

77. Brackett DM, Qing F, Amieux PS, Sellers DL, Horner PJ, Morris DR: FMR1 transcript isoforms: association with polyribosomes; regional and developmental expression in mouse brain. PLOS One 2013, 8:e58296.

78. Sittler A, Devys D, Weber C, Mandel JL: Alternative splicing of exon 14 determines nuclear or cytoplasmic localisation of $\mathrm{fmr} 1$ protein isoforms. Hum Mol Genet 1996, 5:95-102.

79. Bagni $C$, Oostra BA: Fragile $X$ syndrome: from protein function to therapy. Am J Med Genet A 2013, 161A:2809-2821.

80. Tassone F, De Rubeis S, Carosi C, La Fata G, Serpa G, Raske C, Willemsen R, Hagerman PJ, Bagni C: Differential usage of transcriptional start sites and polyadenylation sites in FMR1 premutation alleles. Nucleic Acids Res 2011, 39:6172-6185.

81. D'Hulst C, Heulens I, Brouwer JR, Willemsen R, De Geest N, Reeve SP, De Deyn PP, Hassan BA, Kooy RF: Expression of the GABAergic system in animal models for fragile $X$ syndrome and fragile $X$ associated tremor/ ataxia syndrome (FXTAS). Brain Res 2009, 1253:176-183.

82. Hagerman RJ, Leehey M, Heinrichs W, Tassone F, Wilson R, Hills J, Grigsby J, Gage B, Hagerman PJ: Intention tremor, parkinsonism, and generalized brain atrophy in male carriers of fragile X. Neurology 2001, 57:127-130.

83. Hashimoto R, Srivastava S, Tassone F, Hagerman RJ, Rivera SM: Diffusion tensor imaging in male premutation carriers of the fragile $\mathrm{X}$ mental retardation gene. Mov Disord 2011, 26:1329-1336.

84. Porcellini E, Davis EJ, Chiappelli M, lanni E, Di Stefano G, Forti P, Ravaglia G, Licastro F: Elevated plasma levels of alpha-1-anti-chymotrypsin in age-related cognitive decline and Alzheimer's disease: a potential therapeutic target. Curr Pharm Des 2008, 14:2659-2664.

85. Buxbaum JN, Ye Z, Reixach N, Friske L, Levy C, Das P, Golde T, Masliah E, Roberts AR, Bartfai T: Transthyretin protects Alzheimer's mice from the behavioral and biochemical effects of Abeta toxicity. Proc Natl Acad Sci U S A 2008, 105:2681-2686.

86. Chonchaiya W, Tassone F, Ashwood P, Hessl D, Schneider A, Campos L, Nguyen DV, Hagerman RJ: Autoimmune disease in mothers with the FMR1 premutation is associated with seizures in their children with fragile X syndrome. Hum Genet 2010, 128:539-548.

87. Episkopou V, Maeda S, Nishiguchi S, Shimada K, Gaitanaris GA, Gottesman ME, Robertson EJ: Disruption of the transthyretin gene results in mice with depressed levels of plasma retinol and thyroid hormone. Proc Natl Acad Sci US A 1993, 90:2375-2379.

88. Tan H, Poidevin M, Li H, Chen D, Jin P: MicroRNA-277 modulates the neurodegeneration caused by fragile $X$ premutation $r C G G$ repeats. PLoS Genet 2012, 8:e1002681.

89. Alvarez-Mora Ml, Rodriguez-Revenga L, Madrigal I, Torres-Silva F, Mateu-Huertas E, Lizano E, Friedlander MR, Marti E, Estivill X, Mila M: MicroRNA expression profiling in blood from fragile $X$-associated tremor/ataxia syndrome patients. Genes Brain Behav 2013, 12:595-603.

90. Fernandez E, Rajan N, Bagni C: The FMRP regulon: from targets to disease convergence. Front Neurosci 2013, 7:1-9. 
91. Kratovac S, Corbin JG: Developmental changes in expression of inhibitory neuronal proteins in the fragile $X$ syndrome mouse basolateral amygdala. Brain Res 2013, 1537:69-78.

92. Cao Z, Hulsizer S, Tassone F, Tang HT, Hagerman RJ, Rogawski MA, Hagerman PJ, Pessah IN: Clustered burst firing in FMR1 premutation hippocampal neurons: amelioration with allopregnanolone. Hum Mol Genet 2012, 21:2923-2935.

93. Cao Z, Hulsizer S, Cui Y, Pretto DL, Kim KH, Hagerman PJ, Tassone F, Pessah IN: Enhanced asynchronous $\mathrm{Ca}(2+)$ oscillations associated with impaired glutamate transport in cortical astrocytes expressing Fmr1 gene premutation expansion. J Biol Chem 2013, 288:13831-13841.

94. Hunsaker MR, Kim K, Willemsen R, Berman RF: CGG trinucleotide repeat length modulates neural plasticity and spatiotemporal processing in a mouse model of the fragile $\mathrm{X}$ premutation. Hippocampus 2012, 22:2260-2275.

95. Iliff AJ, Renoux AJ, Krans A, Usdin K, Sutton MA, Todd PK: Impaired activity-dependent FMRP translation and enhanced mGluR-dependent LTD in fragile $X$ premutation mice. Hum Mol Genet 2013, 22:1180-1192.

96. Farzin F, Perry H, Hessl D, Loesch D, Cohen J, Bacalman S, Gane L, Tassone F, Hagerman P, Hagerman R: Autism spectrum disorders and attention-deficit/ hyperactivity disorder in boys with the fragile X premutation. J Dev Behav Pediatr 2006, 27:S137-S144.

97. Aziz M, Stathopulu E, Callias M, Taylor C, Turk J, Oostra B, Willemsen R, Patton M: Clinical features of boys with fragile $\mathrm{X}$ premutations and intermediate alleles. Am J Med Genet B Neuropsychiatr Genet 2003, 121:119-127.

98. Cunningham $\mathrm{CL}$, Martinez Cerdeno $\mathrm{V}$, Navarro Porras $\mathrm{E}$, Prakash AN, Angelastro JM, Willemsen R, Hagerman PJ, Pessah IN, Berman RF, Noctor SC: Premutation CGG-repeat expansion of the Fmr1 gene impairs mouse neocortical development. Hum Mol Genet 2011, 20:64-79.

99. Noctor SC, Flint AC, Weissman TA, Dammerman RS, Kriegstein AR: Neurons derived from radial glial cells establish radial units in neocortex. Nature 2001, 409:714-720.

100. Englund C, Fink A, Lau C, Pham D, Daza RA, Bulfone A, Kowalczyk T, Hevner RF: Pax6, Tbr2, and Tbr1 are expressed sequentially by radial glia, intermediate progenitor cells, and postmitotic neurons in developing neocortex. J Neurosci 2005, 25:247-251.

101. Hunsaker MR, von Leden RE, Ta BT, Goodrich-Hunsaker NJ, Arque G, Kim K, Willemsen R, Berman RF: Motor deficits on a ladder rung task in male and female adolescent and adult CGG knock-in mice. Behav Brain Res 2011, 222:117-121.

102. Diep AA, Hunsaker MR, Kwock R, Kim K, Willemsen R, Berman RF: Female CGG knock-in mice modeling the fragile $X$ premutation are impaired on a skilled forelimb reaching task. Neurobiol Learn Mem 2012, 97:229-234.

103. Gallistel CR: The Organization of Learning. Cambridge, MA: MIT Press; 1993.

104. Hunsaker MR, Rosenberg JS, Kesner RP: The role of the dentate gyrus, CA3a, b, and CA3c for detecting spatial and environmental novelty. Hippocampus 2008, 18:1064-1073.

105. Brouwer JR, Willemsen R, Oostra BA: The FMR1 gene and fragile X-associated tremor/ataxia syndrome. Am J Med Genet B Neuropsychiatr Genet 2009, 150B:782-798.

106. Hunsaker MR, Arque G, Berman RF, Willemsen R, Hukema RK: Mouse models of the fragile $x$ premutation and the fragile $X$ associated tremor/ ataxia syndrome. Results Probl Cell Differ 2012, 54:255-269.

107. Hoem G, Raske CR, Garcia-Arocena D, Tassone F, Sanchez E, Ludwig AL, Iwahashi CK, Kumar M, Yang JE, Hagerman PJ: CGG-repeat length threshold for FMR1 RNA pathogenesis in a cellular model for FXTAS. Hum Mol Genet 2011, 20:2161-2170.

108. Handa V, Goldwater D, Stiles D, Cam M, Poy G, Kumari D, Usdin K: Long CGG-repeat tracts are toxic to human cells: implications for carriers of Fragile X premutation alleles. FEBS Lett 2005, 579:2702-2708.

109. Aumiller V, Graebsch A, Kremmer E, Niessing D, Forstemann K: Drosophila pur-alpha binds to trinucleotide-repeat containing cellular RNAs and translocates to the early oocyte. RNA Biol 2012, 9:633-643.

110. Jin P, Duan R, Qurashi A, Qin Y, Tian D, Rosser TC, Liu H, Feng Y, Warren ST: Pur alpha binds to rCGG repeats and modulates repeat-mediated neurodegeneration in a Drosophila model of fragile $X$ tremor/ataxia syndrome. Neuron 2007, 55:556-564.

111. Fenelon K, Mukai J, Xu B, Hsu PK, Drew L, Karayiorgou M, Fischbach GD, Macdermott AB, Gogos JA: Deficiency of Dgcr8, a gene disrupted by the 22q11.2 microdeletion, results in altered short-term plasticity in the prefrontal cortex. Proc Natl Acad Sci U S A 2011, 108:4447-4452.

112. Stark KL, Xu B, Bagchi A, Lai WS, Liu H, Hsu R, Wan X, Pavlidis P, Mills AA, Karayiorgou M, Gogos JA: Altered brain microRNA biogenesis contributes to phenotypic deficits in a 22q11-deletion mouse model. Nat Genet 2008, 40:751-760.

113. Schaefer A, O'Carroll D, Tan CL, Hillman D, Sugimori M, Llinas R, Greengard P: Cerebellar neurodegeneration in the absence of microRNAs. J Exp Med 2007, 204:1553-1558.

114. Davis TH, Cuellar TL, Koch SM, Barker AJ, Harfe BD, McManus MT, Ullian EM: Conditional loss of Dicer disrupts cellular and tissue morphogenesis in the cortex and hippocampus. J Neurosci 2008, 28:4322-4330.

115. Damiani D, Alexander JJ, O'Rourke JR, McManus M, Jadhav AP, Cepko CL, Hauswirth WW, Harfe BD, Strettoi E: Dicer inactivation leads to progressive functional and structural degeneration of the mouse retina. $J$ Neurosci 2008, 28:4878-4887.

116. Zu T, Gibbens B, Doty NS, Gomes-Pereira M, Huguet A, Stone MD, Margolis J, Peterson M, Markowski TW, Ingram MA, Nan Z, Forster C, Low WC, Schoser B, Somia NV, Clark HB, Schmechel S, Bitterman PB, Gourdon G, Swanson MS, Moseley M, Ranum LP: Non-ATG-initiated translation directed by microsatellite expansions. Proc Natl Acad Sci U S A 2011, 108:260-265.

117. Pearson CE: Repeat associated non-ATG translation initiation: one DNA, two transcripts, seven reading frames, potentially nine toxic entities! PLoS Genet 2011, 7:e1002018.

doi:10.1186/1866-1955-6-25

Cite this article as: Berman et al: Mouse models of the fragile $X$

premutation and fragile $\mathrm{X}$-associated tremor/ataxia syndrome. Journal of Neurodevelopmental Disorders 2014 6:25.

\section{Submit your next manuscript to BioMed Central and take full advantage of:}

- Convenient online submission

- Thorough peer review

- No space constraints or color figure charges

- Immediate publication on acceptance

- Inclusion in PubMed, CAS, Scopus and Google Scholar

- Research which is freely available for redistribution
Submit your manuscript at
www.biomedcentral.com/submit

Submit your manuscript at
www.biomedcentral.com/submit 